\title{
A pH-Triggered, Self-Assembled, and Bioprintable Hybrid Hydrogel Scaffold for Mesenchymal Stem Cell Based Bone Tissue Engineering
}

Chen Zhao, ${ }^{\dagger,+, \#}$ Nader Taheri Qazvini, ${ }^{\S, \#}$ Monirosadat Sadati, ${ }^{\S, \|}$ Zongyue Zeng, ${ }^{+, \perp}$ Shifeng Huang, ${ }^{\dagger, \neq}$ Ana Losada De La Lastra, ${ }^{\nabla}$ Linghuan Zhang, ${ }^{\ddagger}, \perp$ Yixiao Feng, ${ }^{\dagger, \dagger}$ Wei Liu, ${ }^{\dagger, \downarrow}$ Bo Huang, Bo Zhang, ${ }^{\ddagger}$ Zhengyu Dai, Zhenyu Ye, ${ }^{\ddagger} \bullet$ Ling Zhao, ${ }^{\dagger,}$ Daigui Cao,,,$+ \diamond$ Lijuan Yang, Michael J. Lee, ${ }^{\ddagger}$ Jennifer Moriatis Wolf, ${ }^{\ddagger}$ Russell R. Reid, ${ }^{*}$, Matthew Tirrell, $^{\S, \|}$ Wei Huang, ${ }^{*, \dagger}$ Juan J. de Pablo, $, \S, \|$ and Tong-Chuan $\mathrm{He}^{*, * \bullet}$

${ }^{\dagger}$ Departments of Orthopedic Surgery, Clinical Laboratory Medicine, Breast Surgery, Burn and Plastic Surgery, Otolaryngology-Head and Neck Surgery, and Obstetrics and Gynecology, the First Affiliated Hospital of Chongqing Medical University, Chongqing 400016, China

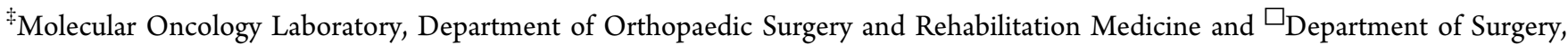
Laboratory of Craniofacial Biology and Development, Section of Plastic Surgery, The University of Chicago Medical Center, Chicago, Illinois 60637, United States

${ }^{\S}$ Institute for Molecular Engineering, The University of Chicago, Chicago, Illinois 60637, United States

"Argonne National Laboratory, Argonne, Illinois 60439, United States

${ }^{\perp}$ Ministry of Education Key Laboratory of Diagnostic Medicine and School of Laboratory Medicine, the Affiliated Hospitals of Chongqing Medical University, Chongqing 400016, China

${ }^{\nabla}$ Department of Chemistry, Imperial College London, London SW7 2AZ, U.K.

ODepartment of Clinical Laboratory Medicine, the Second Affiliated Hospital of Nanchang University, Nanchang 330031, China

Key Laboratory of Orthopaedic Surgery of Gansu Province and the Department of Orthopaedic Surgery, the Second Hospital of Lanzhou University, Lanzhou 730030, China

II Department of Orthopaedic Surgery, Chongqing Hospital of Traditional Chinese Medicine, Chongqing 400021, China

${ }^{\&}$ Department of Orthopaedic Surgery, Xiangya Second Hospital of Central South University, Changsha 410011, China

- Department of General Surgery, the Second Affiliated Hospital of Soochow University, Suzhou 215004, China

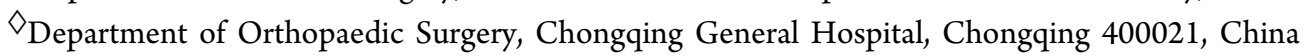

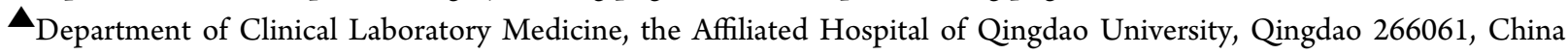

Supporting Information

ABSTRACT: Effective bone tissue engineering can restore bone and skeletal functions that are impaired by traumas and/or certain medical conditions. Bone is a complex tissue and functions through orchestrated interactions between cells, biomechanical forces, and biofactors. To identify ideal scaffold materials for effective mesenchymal stem cell (MSC)-based bone tissue regeneration, here we develop and characterize a composite nanoparticle hydrogel by combining carboxymethyl chitosan (CMCh) and amorphous calcium phosphate (ACP) (designated as CMCh-ACP hydrogel). We demonstrate that the CMCh-ACP hydrogel is readily prepared by incorporating glucono $\delta$-lactone (GDL) into an aqueous dispersion or rehydrating the acidic freeze-dried nanoparticles in a $\mathrm{pH}$-triggered controlled-assembly fashion. The CMCh-ACP hydrogel exhibits excellent biocompatibility and effectively supports MSC proliferation and cell adhesion. Moreover, while augmenting BMP9-induced osteogenic differentiation, the CMCh-ACP hydrogel itself is osteoinductive and induces the expression of osteoblastic regulators and bone markers in MSCs continued...
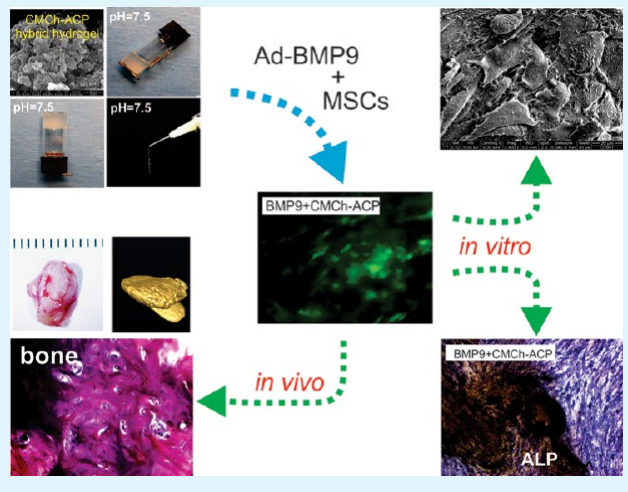

Received: October 31, 2018

Accepted: February 8, 2019

Published: February 8, 2019 
in vitro. The CMCh-ACP scaffold markedly enhances the efficiency and maturity of BMP9-induced bone formation in vivo, while suppressing bone resorption occurred in long-term ectopic osteogenesis. Thus, these results suggest that the $\mathrm{pH}$ responsive self-assembled CMCh-ACP injectable and bioprintable hydrogel may be further exploited as a novel scaffold for osteoprogenitor-cell-based bone tissue regeneration.

KEYWORDS: bone tissue engineering, mesenchymal stem cells, BMP9, carboxymethyl chitosan (CMCh), amorphous calcium phosphate (ACP), nanoparticles, hydrogels

\section{INTRODUCTION}

Bone tissue engineering holds promise to restore bone and skeletal tissue functions that are compromised by large segmental defects, severe fracture nonunion, and/or clinical conditions including cancer resection and bacterial infections. ${ }^{1}$ Approximately 1.6 million bone grafts are carried out each year for bone defect repair in the United States alone. ${ }^{1}$ The morbidity and disabilities associated with bone defects and nonunion fracture pose significant social economic burdens on the society. While serving as a traditional gold standard for bone defect repair, bone autografting is often associated with multiple limitations such as donor site morbidity, bone tissue reshaping, long recovery time, and substantial local tissue damage. ${ }^{1}$ The alternative allogenic bone graft may solicit host immune response or have risks of transmitting diseases. ${ }^{1}$ Thus, effective bone tissue engineering has become an attractive alternative to bone defect repair.

Bone is a complex tissue. Bone formation and remodeling are controlled by well-regulated interactions between cells, the extracellular matrix, biomechanical forces, and biological factors. ${ }^{1-3}$ Thus, effective bone tissue engineering mandates a multidisciplinary approach and minimally requires three critical components: osteogenic progenitors, bone-forming factors, and osteoinductive and/or osteoconductive scaffolds. ${ }^{1,4}$ Osteoprogenitors are usually derived from mesenchymal stem cells (MSCs), which are presented in numerous tissues including bone marrow stroma and adipose tissues. ${ }^{2,5-10}$ Although many growth factors and signaling molecules have been shown to regulate osteogenic differentiation, ${ }^{2,11-16}$ bone morphogenetic proteins (BMPs) are considered the most potent osteoinductive factors both in vitro and in vivo, ${ }^{2,3}$ and we showed that BMP9 is the most potent bone-forming factor among the 14 types of BMPs. ${ }^{2,3,17-28}$ Thus, it is conceivable that BMP9-transduced MSCs, along with ideal scaffolds, would significantly enhance bone regeneration for repairing bone defects and fracture nonunion.

An optimal scaffold can be either osteoconductive and/or osteoinductive and provide a cell-friendly environment for bone progenitors to proliferate and differentiate into osteocytes. However, commonly used scaffolds usually consist of bioactive glasses, calcium phosphates (e.g., hydroxyapatite and $\beta$ tricalcium phosphate), and biopolymers without or with limited osteoinductivity. ${ }^{1,29}$ Thus, there is an unmet need to develop novel scaffolds that are osteoinductive, cell-friendly, and injectable for stem-cell-based bone tissue engineering. ${ }^{1,29}$ Injectable hydrogels are attractive scaffolds in this regard, especially for filling bone defects that are difficult for traditional bone grafts to fulfill the repair.

Here, we developed a composite nanoparticle hydrogel by synthesizing carboxymethyl chitosan ( $\mathrm{CMCh}$ )-stabilized amorphous calcium phosphate (ACP) nanoparticles, designated as CMCh-ACP hybrid gel. Similar to its highly stable crystalline phase of calcium phosphate such as hydroxyapatite, ACP is a biological precursor for the formation of complex calcium phosphate structures such as bone and tooth yet exhibits excellent cell attachment capability and is highly biodegradable to yield abundant calcium and phosphate for bone formation. ${ }^{30-32}$ However, ACP is highly unstable and easily converts to other stable phases of calcium phosphate. In this study, we utilized a commonly used polyanionic derivative of chitosan, carboxymethyl chitosan (CMCh), to stabilize the ACP nanoclusters and formed stable CMCh-ACP nanoparticles. Chitosan and its derivatives are biocompatible, biodegradable, antibacterial, and hemostatic. ${ }^{33-35}$ Chitosan is a polycationic linear polysaccharide polymer derived from chitin, which can be easily obtained from renewable resources, such as the shell of shellfish, and the wastes of the seafood industry. ${ }^{33-35}$ It has been extensively documented that chitosan exhibits excellent biocompatibility, high biodegradability, low allergenicity, and antibacterial and wound-healing activities. ${ }^{33-35}$ However, the poor solubility of chitosan in neutral and alkaline media limits its direct applications in the pharmaceutical and biomedical fields. Various chemical modifications of chitosan as composites or hydrogels have significantly expanded its functional properties.

We showed that the CMCh-ACP hydrogels can be prepared by the incorporation of glucono $\delta$-lactone (GDL) into an aqueous dispersion or rehydration of acidic freeze-dried nanoparticles in a $\mathrm{pH}$-triggered self-assembly manner. Using the adipose-derived mesenchymal stem cells iMADs, we found that the CMCh-ACP hybrid hydrogel was biocompatible and supported cell proliferation and cell adhesion. Moreover, the hydrogel was osteoinductive and significantly enhanced BMP9induced osteogenic markers of MSCs. In vivo studies further revealed that the CMCh-ACP hybrid hydrogel effectively promoted BMP9-induced bone formation and inhibited bone resorption in the extended ectopic osteogenesis. Collectively, our work represents the first example of using the CMCh-ACP nanoparticles to create an injectable or bioprintable hybrid hydrogel. We are also the first to demonstrate that the controlled assembly of the polymer-stabilized ACP nanoparticles to form elastic hydrogels can be accomplished by $\mathrm{pH}$ changes. Thus, our findings strongly suggest that the CMCh-ACP hydrogel may be developed as a novel scaffold for stem-cell-based bone tissue engineering.

\section{MATERIALS AND METHODS}

2.1. Synthesis of the CMCh-ACP Hybrid Nanoparticles and Hydrogel. The CMCh-ACP hybrid nanoparticles were synthesized by dropwise addition of $10 \mathrm{mM}$ phosphate dibasic $\left(\mathrm{K}_{2} \mathrm{HPO}_{4}\right)$ solution into a premixed solution of $20 \mathrm{mM}$ calcium chloride dihydrate $\left(\mathrm{CaCl}_{2}\right.$. $2 \mathrm{H}_{2} \mathrm{O}$ ) and carboxymethyl chitosan ( $\mathrm{CMCh}$, deacetylation degree $90 \%$, Santa Cruz Biotechnology, Inc.) aqueous solution stirred at 1000 rpm at room temperature. The concentrations of calcium chloride, potassium phosphate, and $\mathrm{CMCh}$ in the final dispersion were $10 \mathrm{mM}, 5$ $\mathrm{mM}$, and $2 \mathrm{mg} / \mathrm{mL}$, respectively. The nanoparticles were separated by centrifugation, lyophilized at $-4{ }^{\circ} \mathrm{C}$, and stored at $-80{ }^{\circ} \mathrm{C}$ until use. The controlled sample (ACP) was also synthesized without the addition of $\mathrm{CMCh}$. CMCh-ACP hydrogels were prepared by the incorporation of GDL $(40 \mathrm{mM})$ into a basic aqueous dispersion (100 $\mathrm{mg} / \mathrm{mL}$ ) of the freeze-dried hybrid nanoparticles $(\mathrm{pH} \sim 11.5)$. 
Alternatively, the hydrogels can be prepared by rehydration of $100 \mathrm{mg}$ of acidic freeze-dried nanoparticles in $1.0 \mathrm{~mL}$ of PBS followed by adjusting the $\mathrm{pH}$ to $7.5-7.6$ using $0.1 \mathrm{M} \mathrm{NaOH}$ solution and mixing with two interconnected syringes.

2.2. Characterization of CMCh-ACP Hybrid Nanoparticles. The as-synthesized and freeze-dried $\mathrm{CMCh}-\mathrm{ACP}$ hybrid nanoparticles and the control materials (i.e., $\mathrm{CMCh}$ and $\mathrm{ACP}$ ) were characterized for their sizes and $\zeta$-potentials by dynamic light scattering (DLS) (Zetasizer Nano-ZS, Malvern, PA). All measurements were carried out at $25{ }^{\circ} \mathrm{C}$ using $1 \mathrm{~mL}$ Malvern disposable polystyrene cuvettes and DTS 1070 folded capillary cells for size and $\zeta$-potential measurements, respectively. To redisperse the freeze-dried nanoparticles in water, 4$5 \mathrm{mg} / \mathrm{mL}$ dispersion in Milli-Q water was sonicated for $20 \mathrm{~min}$. The kinetics of $\mathrm{pH}$-triggered self-assembly of the $\mathrm{CMCh}$-ACP nanoparticles was investigated by addition of GDL (Sigma-Aldrich) $(10 \mathrm{mM})$ into a 1 $\mathrm{mg} / \mathrm{mL}$ dispersion of the hybrid nanoparticles adjusted to $\mathrm{pH} 11$ at $t=$ 0 . The size of the aggregates was then monitored for $30 \mathrm{~min}$ by dynamic light scattering.

The freeze-dried nanoparticles were also imaged by scanning electron microscopy (SEM) (FEI Nova NanoSEM 230, accelerating voltage of $15 \mathrm{kV}$, working distance of $4.6 \mathrm{~mm}$ ) and transmission electron microscopy (TEM) (FEI Tecnai F30, accelerating voltage of $200 \mathrm{kV}$ ) for their morphology and internal structure, respectively. Fourier transform infrared spectroscopy (FTIR) (PerkinElmer Spectrum 400 FTIR) and synchrotron wide-angle X-ray scattering (WAXS) measurements were used to determine the calcium phosphate polymorphs in the freeze-dried CMCh-ACP nanoparticles and the control sample. The FTIR spectra were recorded between 4000 and $500 \mathrm{~cm}^{-1}$ with a spectral resolution of $4 \mathrm{~cm}^{-1}$. For the WAXS measurements, the samples were inserted in sealed Charlessupper quartz capillaries $(d=1.5 \mathrm{~mm})$. The experiments were performed using a beam energy of $12 \mathrm{keV}(\lambda=1.034 \AA)$ with typical exposure times of $\sim 1 \mathrm{~s}$ at the Sector 12-ID-B beamline of the Advanced Photon Source at the Argonne National Laboratory (Argonne, IL).

2.3. Assessment of $\mathrm{pH}$ Responsiveness, Viscosity, and Injectability of the CMCh-ACP Hybrid Hydrogel. The viscosities of CMCh-ACP hybrid hydrogels were tested at room temperature. Briefly, $100 \mathrm{mg}$ of CMCh-ACP hybrid powder was mixed with $1000 \mu \mathrm{L}$ of PBS (10 wt \%) and stirred until the CMCh-ACP hybrid particle dispersed uniformly in cylindrical bottles with a flat base, followed by the addition of $50 \mu \mathrm{L}$ of $0.1 \mathrm{M} \mathrm{NaOH}$ to raise the $\mathrm{pH}$ to $\sim 7.5$. The liquid levels and gelling status were checked after $1 \mathrm{~h}$. To assess the gelling process of the hydrogels $(\mathrm{pH} 7.5)$, the vial inversion tests were carried out at 4 and $36 \mathrm{~h}$. To assess the injectability of the hybrid material, CMCh-ACP hybrid gels $(\mathrm{pH} 7.5)$ were constructed in $5 \mathrm{~mL}$ syringes with needles. At 4 and $36 \mathrm{~h}$ after preparation, pressure $(5 \mathrm{~N} /$ $\mathrm{m}^{2}$ ) was applied to the syringe plugs. Images of the hybrid hydrogel flow through the needles were recorded. Unless indicated otherwise, the CMCh-ACP hydrogel used in this study was adjusted to $\mathrm{pH} 7.5$.

The $\mathrm{pH}$-triggered gelation, shear-thinning behavior, and self-healing properties were also explored using small-amplitude oscillatory rheology measurements. The measurements were carried out at 25 ${ }^{\circ} \mathrm{C}$ on a Discovery Hybrid rheometer (HR2, TA Instruments, USA) using a $2^{\circ}$ stainless steel cone and plate geometry (diameter $20 \mathrm{~mm}$ ) with a truncation gap of $59 \mu \mathrm{m}$. To avoid losing water during the measurements, a solvent trap was used. To investigate the $\mathrm{pH}$-triggered gelation, GDL $(40 \mathrm{mM})$ was mixed with a $2.5 \mathrm{wt} \% \mathrm{CMCh}-\mathrm{ACP}$ dispersion and the mixture was then transferred to the rheometer. Subsequently, the storage modulus $G^{\prime}$ and loss modulus $G^{\prime \prime}$ were monitored using time sweep measurements for $60 \mathrm{~min}$ at a strain and frequency of $1 \%$ and $1 \mathrm{~Hz}$, respectively. The shear-thinning behavior was determined by shear rate sweep measurements from 0.001 to 10 $\mathrm{s}^{-1}$. To investigate the self-healing properties, multiple cycles of time sweep measurements were performed on the CMCh-ACP hydrogels (10 wt \%) by applying $100 \%$ strain for $1 \mathrm{~min}$ at $1 \mathrm{~Hz}$ to destroy the gel structure, followed by recovery measurements at $1 \%$ strain for $5 \mathrm{~min}$ at 1 $\mathrm{Hz}$. The linear viscoelastic region was assessed by strain sweep measurements performed from 0.01 to $1000 \%$ at $1 \mathrm{~Hz}$. Shear rate sweep, strain sweep, and recovery measurements were performed at $\mathrm{pH}$ 7.5. All measurements were done in triplicate $(n=3)$.
2.4. Cell Culture and Chemicals. Human HEK-293 cells were obtained from ATCC (Manassas, VA). 293pTP and RAPA cells were previously described. ${ }^{36,37}$ Mouse mesenchymal stem cell line iMADs were previously characterized. ${ }^{38}$ All cells were cultured in complete DMEM containing $10 \%$ fetal bovine serum (FBS, Invitrogen/Thermo Fisher, Waltham, MA) with penicillin (100 units/mL) and streptomycin $(100 \mu \mathrm{g} / \mathrm{mL})$ as described. ${ }^{21,39-41}$ Unless otherwise indicated, all other reagents were obtained from Sigma-Aldrich (St. Louis, MO) or Thermo Fisher Scientific (Waltham, MA).

2.5. Generation of Recombinant Adenoviruses Expressing BMP9, GLuc, GFP, or RFP. Recombinant adenoviruses were generated by using the AdEasy technology as described. ${ }^{42}$ Recombinant adenovirus Ad-BMP9 was previously characterized. ${ }^{17,43-45}$ The coding region of Gaussia luciferase (GLuc) was PCR amplified and subcloned into the shuttle vector pAdTrace-CMV, followed by homologous recombination in bacterial BJ5183 cells to generate recombinant adenoviral vector pAdR-GLuc, which was subsequently used to generate adenovirus AdR-GLuc in 293pTP or RAPA cells. Ad-BMP9 also coexpresses enhanced green fluorescent protein (eGFP), while AdR-GLuc coexpresses monomeric RFP (mRFP). An adenovirus expressing eGFP (Ad-GFP) or monomeric red fluorescent protein (mRFP) (Ad-RFP) was used as a mock infection control. ${ }^{27,39,46}$ To improve infection efficiency, polybrene $(4-8 \mu \mathrm{g} / \mathrm{mL})$ was added to all adenoviral infections as described. ${ }^{47}$

2.6. Hoechst Staining (Apoptosis) Assay. Exponentially growing iMADs cells $\left(10^{5}\right.$ cells per well) were mixed with the CMCh-ACP hybrid gel ( $50 \mu \mathrm{L}$ per well) and seeded in 24 well plates. At 1, 2, 3, 4, and 5 days after plating, culture medium was removed and cells were gently washed with PBS and fixed and stained with the Magic Solution as described. ${ }^{48-51}$ Apoptotic cells were assessed under a fluorescence microscope. All assays were done in triplicate and repeated in three independent batches of experiments.

2.7. Cell Proliferation (WST-1) Assay. Cell proliferation was determined by using the Premixed WST-1 Reagent (Clontech, Mountain View, CA) as described. ${ }^{52,53}$ Specifically, exponentially growing iMADs cells $\left(10^{4}\right.$ cells per well $)$ were mixed with the CMChACP hybrid gel ( $10 \mu \mathrm{L}$ per well) and seeded in 24 well plates. At $1,2,3$, 4 , and 5 days after plating, the WST- 1 substrate was added, followed by incubation at $37{ }^{\circ} \mathrm{C}$ for $1 \mathrm{~h}$ and measurement of $\mathrm{OD}_{440 \mathrm{~nm}}$ on an absorbance microplate reader (EL800, BioTek Instruments). All assays were done in triplicate.

2.8. Cell Survival and Biocompatibility in the CMCh-ACP Hybrid Hydrogel. The iMADs were infected with AdR-GLuc (or AdRFP) for $20 \mathrm{~h}$. The cells were collected and mixed directly with the freshly prepared CMCh-ACP composite hydrogel. The expression of RFP was monitored for up to 15 days, followed by a reinfection with another dose of adenovirus. $\mathrm{RFP}^{+}$cells were recorded.

2.9. Gaussia Luciferase (GLuc) Assay of the iMADs Entrapped in CMCh-ACP Hybrid Gel. The iMADs were infected with AdR-GLuc for $20 \mathrm{~h}$. The infected cells were collected and resuspended in PBS (at $10^{6}$ cells $/ \mathrm{mL}$ ). $100 \mathrm{mg}$ of CMCh-ACP powder was dissolved and mixed with $950 \mu \mathrm{L}$ of the resuspended iMADs cells, followed by the addition of $50 \mu \mathrm{L}$ of $0.1 \mathrm{M} \mathrm{NaOH}$, resulting in the hybrid gel with $\mathrm{pH} 7.5$ to 8 . The cell-gel mixture was kept at $4{ }^{\circ} \mathrm{C}$ for several hours to overnight. $100 \mu \mathrm{L}$ of the cell-gel mix was transferred to 12 well cell culture plates and cultured with $2.0 \mathrm{~mL}$ of complete DMEM. At 3, 6, 9, 12, and 15 days after plating, $50 \mu \mathrm{L}$ of culture medium was transferred for the GLuc activity assay using a BioLux Gaussia Luciferase Assay Kit (New England Biolabs) as described. ${ }^{50,54-56}$ The cell culture wells were refilled with $50 \mu \mathrm{L}$ of complete DMEM medium. All assays were done in triplicate.

2.10. Scanning Electron Microscopy (SEM). The iMADs were infected with Ad-GFP or Ad-BMP9 for $20 \mathrm{~h}$. Approximately $10^{5}$ iMADs cells were mixed with $100 \mu \mathrm{L}$ of freshly prepared CMCh-ACP gel as described above and seeded into 24 well cell culture plates. The cell-gel mix was cultured in complete DMEM or mineralization medium (complete DMEM containing $10 \mathrm{mM} \beta$-glycerophosphate and $50 \mu \mathrm{g} /$ $\mathrm{mL}$ ascorbic acid). The cell-gel mix was subjected to GFP signal recording at 7 days after cell plating, then washing with PBS, and incubating in $2.5 \%$ glutaraldehyde and $0.1 \mathrm{M}$ sodium cacodylate $(\mathrm{NaC})$ 


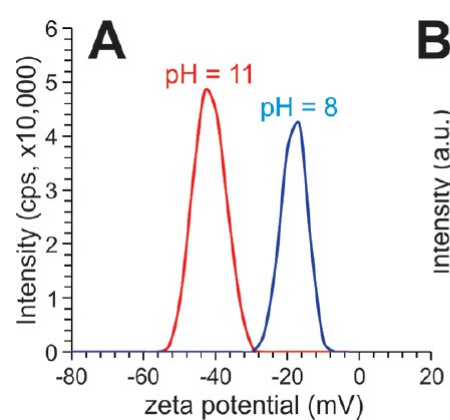

D

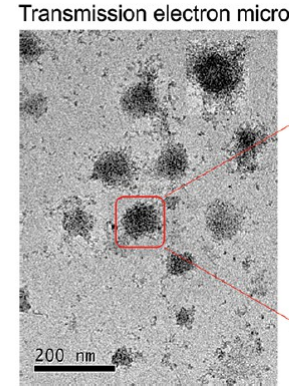

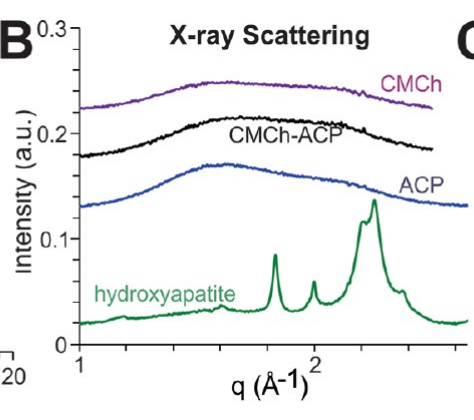

scopy (TEM)

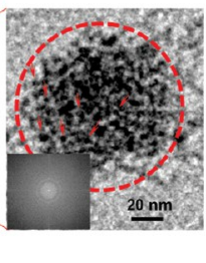

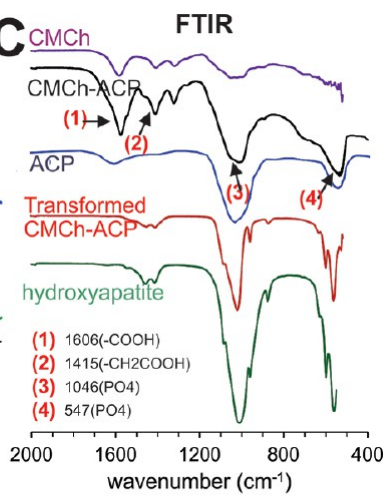

E

Figure 1. Characterization of the CMCh-ACP hybrid nanoparticles. (A) $\zeta$-potential for the hybrid nanoparticles determined by DLS at pH 11.0 and 8.0. (B) Synchrotron WAXS profiles of the CMCh-ACP hybrid gel and its control materials CMCh and ACP. (C) FTIR spectra of the hybrid nanoparticles and the control materials CMCh and ACP. (D) TEM analysis of the CMCh-ACP nanoparticles at two different magnifications. The red arrows indicate representative ACP nanoclusters dispersed in a hybrid nanoparticle at a higher magnification. The fast Fourier transformation of the image (inset) confirms that the nanoparticles are amorphous. (E) SEM micrographs of the hybrid nanoparticles. The experiments were repeated for at least three independent trials. Representative images are shown. ACP, amorphous calcium phosphate; CMCh, carboxymethyl chitosan; DLS, dynamic light scattering; FTIR, Fourier transform infrared spectroscopy; SEM, scanning electron microscopy; TEM, transmission electron microscopy; WAXS, wide-angle X-ray scattering.

solution $\left(1: 1\right.$ ratio) overnight at $4{ }^{\circ} \mathrm{C}$. The samples were then rinsed with $0.1 \mathrm{M} \mathrm{NaC}$ and incubated in $1 \%$ osmium tetroxide and $0.1 \mathrm{M} \mathrm{NaC}$ solution for $1 \mathrm{~h}$. Gradual dehydration of the samples was performed sequentially in $30,50,75,85,95$, and $100 \%$ ethanol at 15 min for each stage, and then the samples were transferred into a critical point dryer (Leica EM CPD300). Lastly, the samples were mounted into aluminum SEM Pin Stub Specimen Mounts with double-sided carbon tape. SEM imaging was carried out by using the FEI Nova Nano SEM230 unit with an accelerating voltage of $5 \mathrm{kV}$.

2.11. Alkaline Phosphatase (ALP) Activity Assay. ALP activities were assessed using the quantitative Great Escape SEAP assay (BD Clontech) and/or histochemical staining as described. ${ }^{57-60}$ Briefly, subconfluent iMADs cells were infected with Ad-BMP9 or Ad-GFP for $20 \mathrm{~h}$. Approximately $10^{4}$ infected iMADs were seeded into each well of 24 well plates for $2 \mathrm{~h}$, followed by adding $50 \mu \mathrm{L}$ of freshly prepared CMCh-ACP hybrid gel to each well. After $1 \mathrm{~h}$, the complete DMEM was added and incubated in the $37{ }^{\circ} \mathrm{C}$ incubator with $5 \% \mathrm{CO}_{2}$. At 3, 5, and 7 days after coincubation, the cells were either lysed for the quantitative ALP assay using the Great Escape SEAP assay kit or fixed for the histochemical staining assay as described. ${ }^{59,60}$ All assays were done in triplicate and repeated in at least three independent experiments.

2.12. Matrix Mineralization Assay (Alizarin Red S Staining). The iMADs cells were infected with Ad-BMP9 or Ad-GFP for $20 \mathrm{~h}$. Approximately $10^{4}$ infected iMADs cells were seeded into each well of 24 well plates for $2 \mathrm{~h}$, followed by adding $50 \mu \mathrm{L}$ of freshly prepared CMCh-ACP hybrid gel to each well. After $1 \mathrm{~h}$, the mineralization medium was added and incubated in the $37{ }^{\circ} \mathrm{C}$ incubator with $5 \% \mathrm{CO}_{2}$ as described..$^{27,53,61-63}$ At 7 days after coincubation, mineralized matrix nodules were visualized by Alizarin Red $S$ staining as described. ${ }^{27,53,61-63}$ The stained calcium mineral deposits were documented under a bright field microscope.

2.13. RNA Isolation and Touchdown Quantitative qPCR (TqPCR) Analysis. Total RNA was isolated by using the NucleoZOL Reagent (Takara Bio USA, Mountain View, CA) and subjected to reverse transcription with hexamer and M-MuLV Reverse Transcriptase (New England Biolabs). The cDNA products were used as templates for TqPCR. The qPCR primers were designed by the Primer3Plus program (Table S1). A TqPCR analysis was carried out as described $^{64}$ using the $2 \times$ SYBR Green qPCR master mix (Bimake, Houston, TX). All assays were performed in triplicate. Gapdh was used as a reference gene. Relative expression was calculated by using the $2^{-\Delta \Delta C t}$ method as described. ${ }^{65-67}$

2.14. Stem Cell Implantation and Ectopic Bone Formation Using CMCh-ACP Hybrid Scaffold in Vivo. All animal study procedures in this study were approved by the Institutional Animal Care and Use Committee (IACUC). The subcutaneous stem cell implantation assay was performed as described..$^{39,53,68}$ The iMADs were subjected to AdBMP9 or AdGFP infection for $24 \mathrm{~h}$; the cells were collected and mixed with or without the CMCh-ACP hybrid gel. The cell-gel mixture $(<100 \mu \mathrm{L})$ was then injected subcutaneously into the flanks of athymic nude mice $(n=5$ per group, $6-8$ weeks old, male; Envigo/Harlan Research Laboratories; $2 \times 10^{6}$ cells per site). At 4, 6, and 8 weeks after implantation, mice from respective groups were sacrificed. The masses were retrieved and fixed in $10 \%$ buffered formalin for micro-computed tomography $(\mu \mathrm{CT})$ imaging and histological evaluation.

2.15. $\mu \mathrm{CT}$ Imaging and Analysis. The retrieved masses were imaged with the $\mu \mathrm{CT}$ component of the GE Triumph imaging system (GE Healthcare, Piscataway, NJ, USA). A single frame of 512 projections of continuous $\mathrm{X}$-ray exposure was used for $\mathrm{CT}$ acquisitions. Volumetric CT images were reconstructed in a $512 \times 512 \times 512$ format with voxel dimensions of $115 \mu \mathrm{m}^{3}$. The image data were analyzed with Amira 5.3 (Visage Imaging, Inc.). The 3D volumetric data were acquired as described. ${ }^{28,56,61,69}$

2.16. Hematoxylin-Eosin Staining and Trichrome Staining. After $\mu \mathrm{CT}$ imaging, the retrieved masses were decalcified for paraffin embedding. Serial sections at $5 \mu \mathrm{m}$ of the embedded specimens were subjected to $\mathrm{H} \& \mathrm{E}$ staining and Masson's Trichrome staining as described. ${ }^{27,54,62}$ 

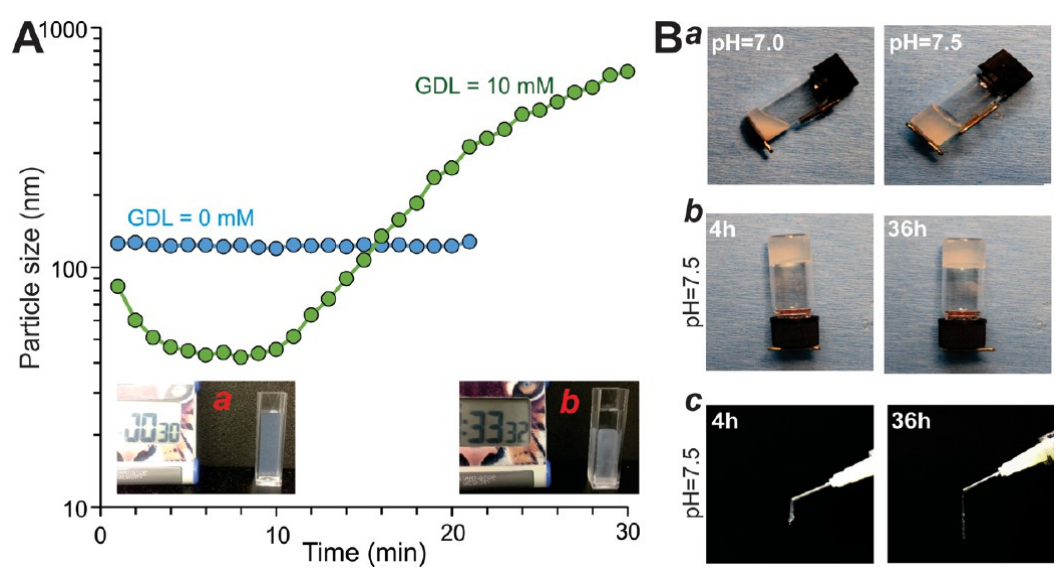

Figure 2. Demonstration of the pH-triggered self-assembly behavior of the CMCh-ACP hybrid nanoparticles and injectability of the formed gel. (A) Size evolution monitored by DLS for the CMCh-ACP dispersions $(1 \mathrm{mg} / \mathrm{mL})$ at $\mathrm{pH} 11.0$ with and without addition of $10 \mathrm{mM}$ GDL. The images of the dispersion at $30 \mathrm{~s} \mathrm{(a)}$ and $33 \mathrm{~min}$ (b) immediately after the addition of GDL. (B) Injectability of the CMCh-ACP hybrid gel. Vial-inversion test on 10 wt \% CMCh-ACP hybrid gels shows the $\mathrm{pH}$-dependent structure of the gel (a). At $\mathrm{pH} 7.5$, the gel remains at the bottom of the vial for a long time (b). Injectability of $\mathrm{CMCh}-\mathrm{ACP}$ gel (at pH 7.5) through medical syringes with needle at 4 and $36 \mathrm{~h}$ after preparation (c). The experiments were repeated for at least three independent trials. Representative images are shown. GDL, glucono $\delta$-lactone.

2.17. Statistical Analysis. All quantitative experiments were carried out in triplicate and/or repeated in three independent experiments. Statistical analysis was done by using Excel's statistics function (Microsoft Office 2016). Statistical significance was determined by one-way analysis of variance and Student's $t$ test. ${ }^{51} p<$ 0.05 was considered statistically significant.

\section{RESULTS}

3.1. Characterization of the CMCh-ACP Nanoparticles and Hydrogel. The size and charge of the CMCh-ACP nanoparticles were analyzed by dynamic light scattering (DLS). We found the size of nanoparticles in the aqueous dispersion was approximately $115 \mathrm{~nm}$ with a polydispersity index of 0.24 . The particles exhibited a negative charge of $-15 \mathrm{mV}$ at $\mathrm{pH} 8$ (Figure 1A). However, due to the polyampholyte nature of the $\mathrm{CMCh}$ polymer, the nanoparticles are expected to show a $\mathrm{pH}$ dependent charge. For instance, the $\zeta$-potential of the particles dropped to $-43 \mathrm{mV}$ at $\mathrm{pH} 11$ (Figure $1 \mathrm{~A}$ ).

Further characterization using wide-angle X-ray scattering (WAXS) and Fourier transform infrared spectroscopy (FTIR) confirmed that the CMCh-ACP nanoparticles were structurally amorphous and comprised amorphous calcium phosphate (ACP) as no diffraction peaks were observed in the WAXS pattern of the CMCh-ACP nanoparticles (Figure 1B). Furthermore, the broad characteristic bands centered at 1064 and $547 \mathrm{~cm}^{-1}$ could be assigned to $\mathrm{PO}_{4}{ }^{3-}$ of amorphous calcium phosphate (Figure 1C). On the other hand, the distinct Bragg reflections in the WAXS pattern and distinct reflections in the FTIR spectrum of the control samples confirmed the crystalline structures in the form of hydroxyapatite (Figure 1B,C).

To further elucidate the internal structure of the freeze-dried nanoparticles, transmission electron microscopy (TEM) was used and identified spherical particles with the average size of approximately $80 \mathrm{~nm}$ in the TEM images (Figure 1D). TEM analysis further revealed that each CMCh-ACP nanoparticle was composed of many small objects, which were believed to be ACP nanoclusters. No crystallites were observed in TEM images as supported by the fast Fourier transform of the images (Figure $1 \mathrm{D}$, inset). Thus, based on the structural characterizations, the $\mathrm{CMCh}-\mathrm{ACP}$ nanoparticles can thus be explained as amorphous structures containing ACP nanoclusters dispersed in the $\mathrm{CMCh}$ polymer matrix.
Furthermore, scanning electron microscopy (SEM) imaging revealed the hybrid gel consisted of micrometer-sized aggregates of the CMCh-ACP nanoparticles with an average size of approximately $30 \mathrm{~nm}$ (Figure $1 \mathrm{E}$ ), which was in clear contrast to that of the control sample, which exhibited an aggregation of needle-like crystals (data not shown). In fact, the average size of the freeze-dried CMCh-ACP nanoparticles was much smaller than the size measured by DLS, confirming that dehydration occurred during the freeze-drying process. Conversely, the size of the rehydrated nanoparticles was shown to be comparable to that of the as-synthesized dispersion of the nanoparticles.

3.2. pH-Triggered Self-Assembly and Injectable Feature of the CMCh-ACP Hybrid Nanoparticles. Since the surface charges of the CMCh-ACP hybrid nanoparticles are $\mathrm{pH}$-dependent, it is conceivable that $\mathrm{pH}$ changes may impact particle interactions so that the electrostatic self-assembly between the nanoparticles would result in the formation of a cohesive injectable gel. As the results show above, the electrostatic self-assembly was confirmed by DLS measurements by which formation of the large aggregates was detected after addition of GDL to a dispersion of the hybrid nanoparticles at $\mathrm{pH}$ 11. Using the GDL as an acidifier, we found that a gradual decrease in the $\mathrm{pH}$ of the dispersion triggered self-assembly at $\mathrm{pH} 7.5$, where both negative and positive charges were present on the surface of the nanoparticles (Figure 2A). In fact, after the addition of GDL, the nanoparticles shrunk and then formed aggregates in which their size increased linearly over time (Figure 2A, inset a). After about $30 \mathrm{~min}$, the aggregates precipitated, and a two-phase system was formed (Figure 2A, inset $b$ ). The observed decay in the size of the nanoparticles in the initial time points after addition of GDL is attributed to the exclusion of water from the nanoparticles due to strong electrostatic interactions between the oppositely charged groups inside the nanoparticles.

We further evaluated the $\mathrm{pH}$-dependent stability and injectability of the CMCh-ACP hybrid materials by vialinversion and injection tests. When the acidified CMCh-ACP freeze-dried aggregates were rehydrated with PBS and adjusted to $\mathrm{pH} 7.5$, the samples solidified and passed the vial-inversion tests, while at $\mathrm{pH} 7.0$ or below, the samples gelled at the bottom of the vial but failed the vial-inversion test (Figure 2B, panel a). 

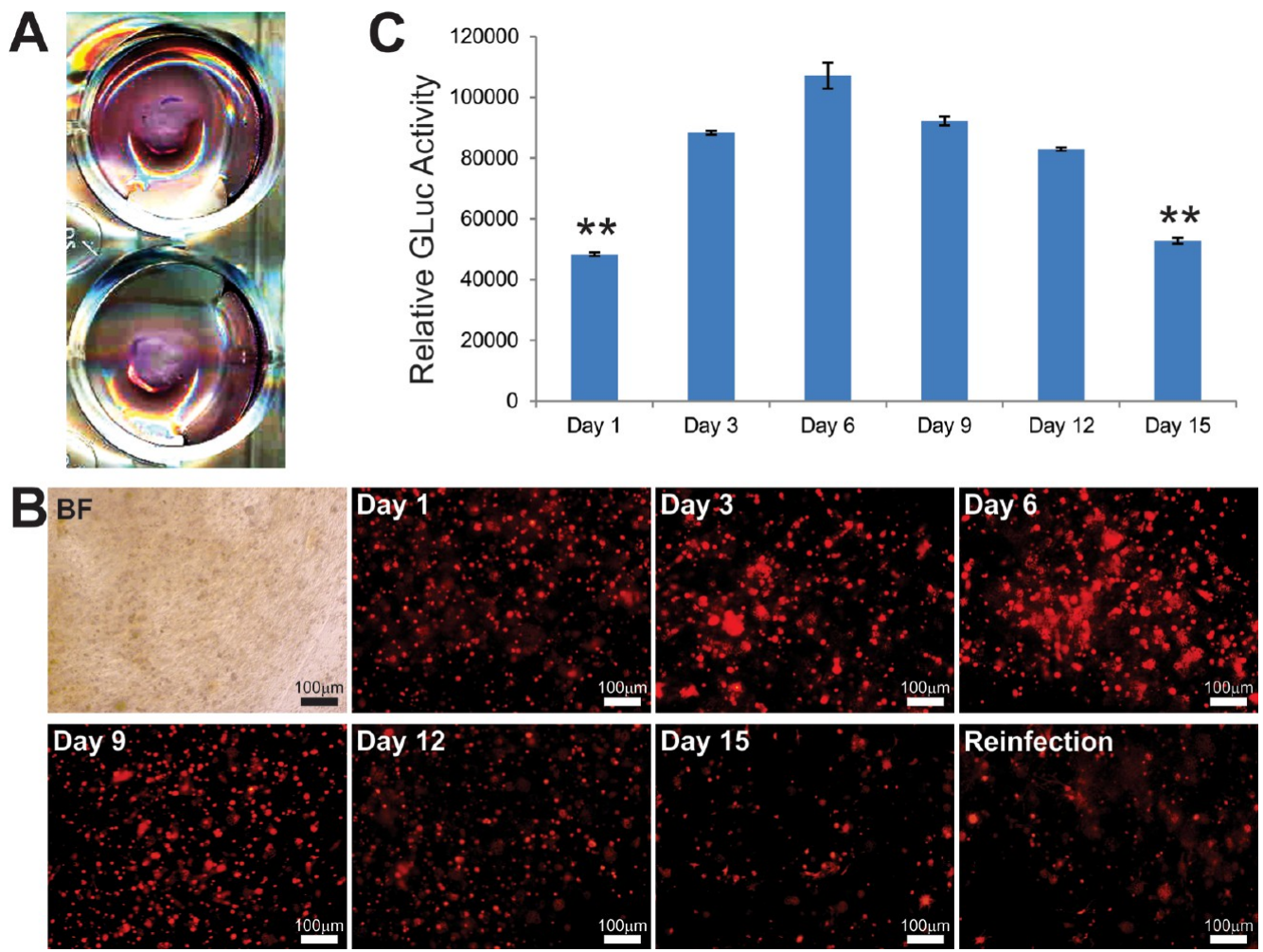

Figure 3. Cell proliferation and survival of MSCs in CMCh-ACP hybrid gel in vitro. (A,B) The MSC iMADs preinfected with AdR-GLuc were mixed with CMCh-ACP hybrid gel, seeded into 12 well plates, and grown with complete DMEM (B). RFP signal was detected at 1, 3, 6, 9, 12, and 15 days. At the 15th day, another dose of Ad-GLuc was added to each well to reinfect iMADs in CMCh-ACP hybrid gel; the RFP signal was recorded three days later (day 18). (C) Gaussia luciferase activity assay. At the indicated time points, an aliquot of the culture media from AdR-GLuc-transduced iMADs cultured in CMCh-ACP hybrid gel was collected for GLuc activity analysis. Each assay condition was done in triplicate. “**” $p<0.01$, compared with the GLuc activity at day 3.

The gelled CMCh-ACP hybrid materials at $\mathrm{pH} 7.5$ were stable and remained at the bottom of the vials for 4 and $36 \mathrm{~h}$ (Figure 2B, panel b). Moreover, the gelled CMCh-ACP hybrid materials at $\mathrm{pH} 7.5$ remained injectable through medical syringes and formed continuous flows without any breakage at 4 and $36 \mathrm{~h}$ after initial formation (Figure 2B, panel c). The $\mathrm{pH}$-triggered gelation, shear-thinning behavior, injectability, and self-healing capability of the hybrid gels were also examined by steady shear and dynamic rheological measurements (Figure S1). After addition of GDL to a $2.5 \mathrm{wt} \% \mathrm{CMCh}-\mathrm{ACP}$ dispersion at $\mathrm{pH} 11$, the $\mathrm{pH}$ decreases gradually, and the rheological behavior of the system shows a slow transition from liquid-like to solid-like, exhibited by a larger $G^{\prime}$ than $G^{\prime \prime}$. Specifically, $\tan (\delta)$, the ratio of $G^{\prime \prime}$ to $G^{\prime}$, decreases to a plateau after $2000 \mathrm{~s}$, manifesting formation of a stable gel (Figure S1A). A $10 \mathrm{wt} \%$ CMCh-ACP gel displayed a high viscosity and an obvious shear-thinning behavior as quantified by steady shear measurements (Figure $\mathrm{S} 1 \mathrm{~B}$ ). We also used strain sweep dynamic measurements to confirm the shear-thinning behavior of the gel. A sharp transition from solid- to liquid-like behavior was observed as the oscillation amplitude exceeded a critical value of around $100 \%$ (Figure S1C). To quantify the self-healing properties of the gels, we employed three cycles of structural destruction and recovery by applying high (100\%) and low (1\%) oscillatory strains. Remarkably, the 10 wt \% CMCh-ACP gel could repeatedly recover its original storage modulus and elasticity immediately after cessation of a high-strain step (Figure S1D). The rapid recovery behavior reflects the reversibility of the electrostatic interactions between the oppositely charged groups on $\mathrm{CMCh}$ -
ACP hybrid nanoparticles. These results indicate that the engineered CMCh-ACP hybrid gel exhibits excellent stability and injectability, which are essential for filling bone defects and potential 3D printing prefabrications for bone tissue engineering.

3.3. Cytotoxicity, Cell Proliferation, and Biocompatibility Analysis of the Mesenchymal Stem Cells Entrapped in CMCh-ACP Hybrid Gel. We next tested the potential cytotoxicity and biocompatibility of the CMCh-ACP hybrid gel in mesenchymal stem cells. When the iMADs cells were mixed with the CMCh-ACP hydrogel, seeded in cell culture plates, and stained with Hoechst 33258 at different time points, we found that positively stained cell nuclei increased in a time-dependent fashion (Figure S2A), indicating that the iMADs entrapped in the hydrogel proliferated rather well. More importantly, the vast majority of the Hoechst 33258 stained cells exhibited healthy nuclei without apparent apoptotic nuclei morphology such as pyknosis and cell shrinking, even at day 5 (Figure S2A).

We further conducted the cell proliferation assay and found that the relative cell proliferation rates for the iMADs mixed with the CMCh-ACP hydrogel were not significantly different from that of the iMADs cells directly grown on $2 \mathrm{D}$ monolayer culture under the same growth conditions $(p>0.05)$ (Figure S2B). Thus, these above results demonstrated that the CMCh-ACP hydrogel does not negatively impact the cell proliferation of iMADs cells.

Nonetheless, since stem-cell-based osteogenesis requires a long-term cell friendly growth environment, we monitored the long-term expression of the reporter genes RFP and GLuc in the 

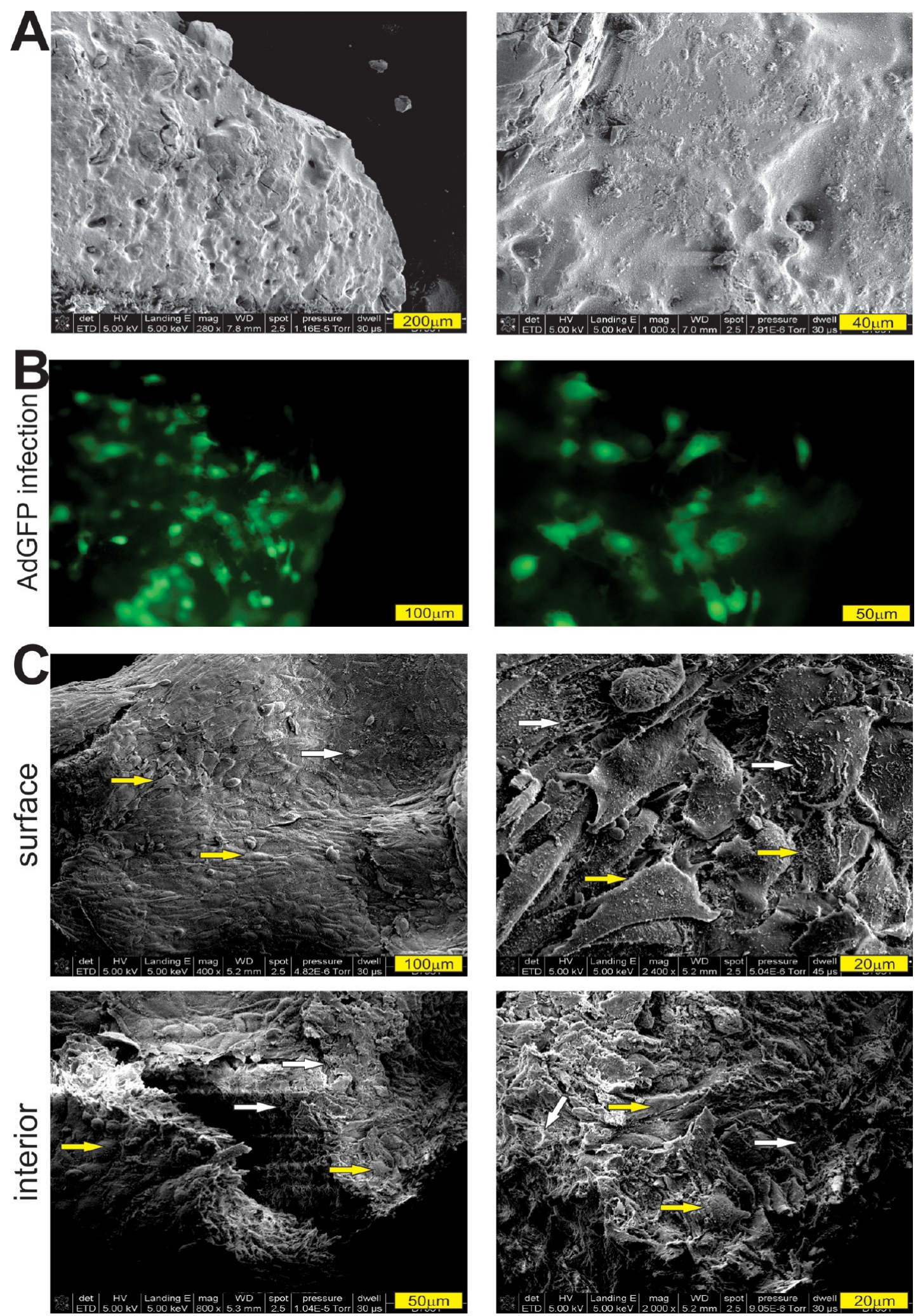

Figure 4. SEM analysis of the cell morphology and matrix mineralization of BMP9-stimulated MSCs cultured in CMCh-ACP hybrid gel. (A) SEM image of the prepared CMCh-ACP hybrid gel ( $\mathrm{pH}$ 7.5) without adhered cell (at two magnifications). (B) The iMADs infected with Ad-BMP9 were mixed with CMCh-ACP hybrid gel. The GFP signal was recorded at 7 days after cell plating. (C) The samples in panel (B) were fixed and subjected to SEM analysis. Cells and mineralized nodules on the surface and interior of the CMCh-ACP hybrid gel were documented (with two magnifications). The iMADs cells are indicated by yellow arrows, while the mineralized nodules are indicated by white arrows. Representative images are shown.

iMADs cells mixed with CMCh-ACP hydrogel 15 (Figure 3A). We found that the adenovirus-mediated expression of RFP in the iMADs cells steadily increased, peaked between 6 and 9 days after plating, and noticeably decreased at day 15 (Figure 3B). As the decreased RFP signal could be caused by the loss of RFP transgene delivered by the adenovirus and/or cell death caused 

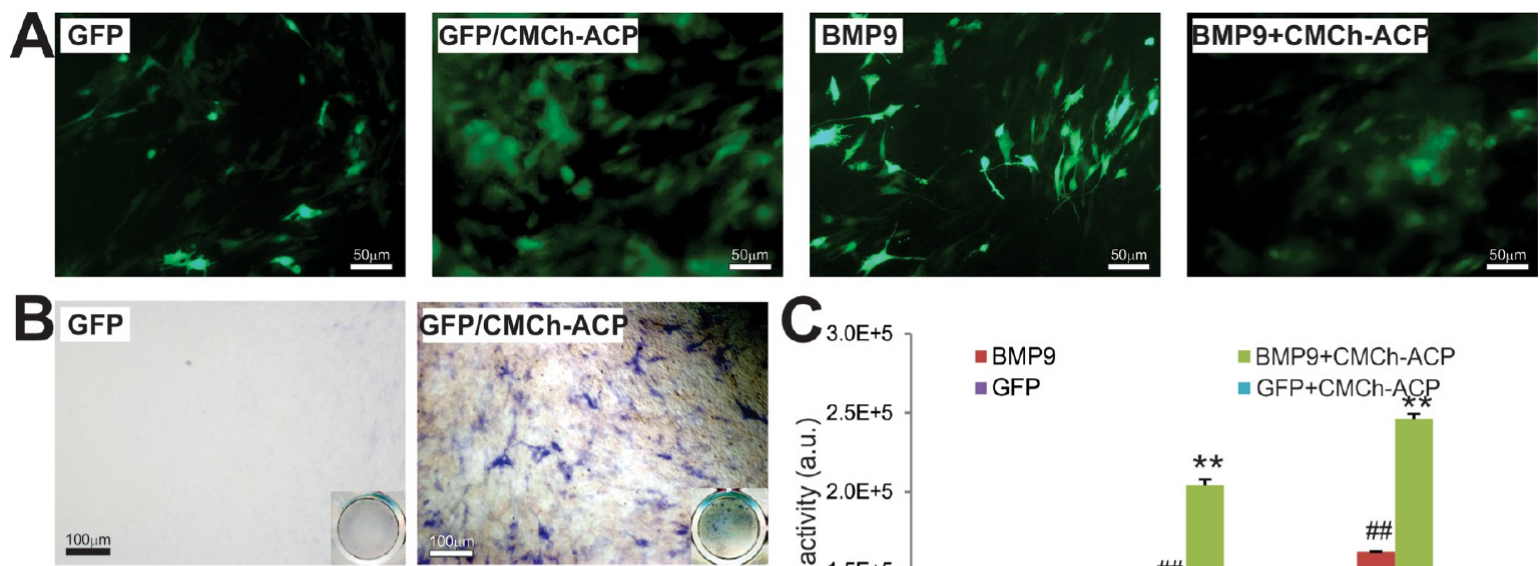

$=\mathrm{BMP} 9+\mathrm{CMCh}-\mathrm{ACP}$
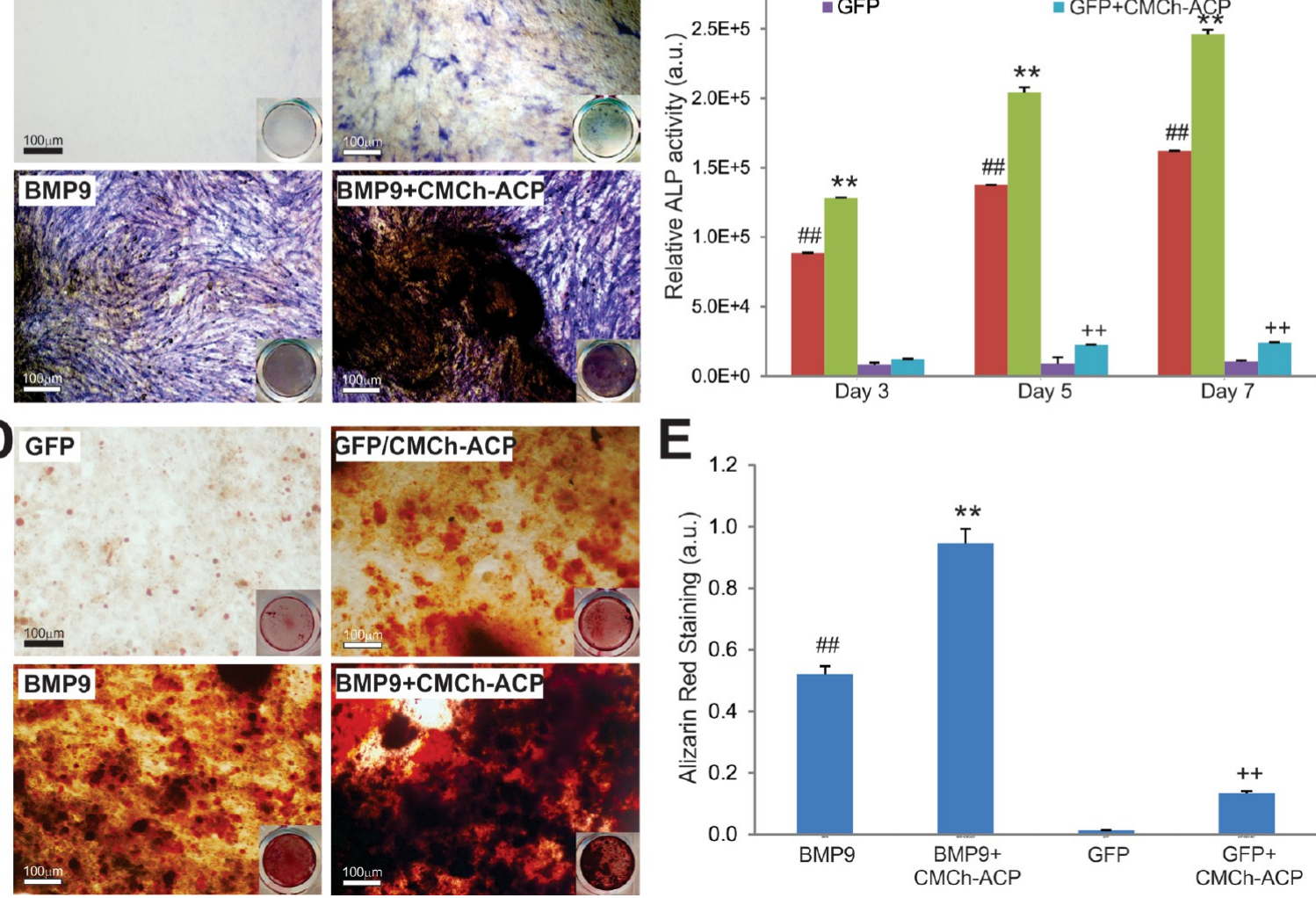

E

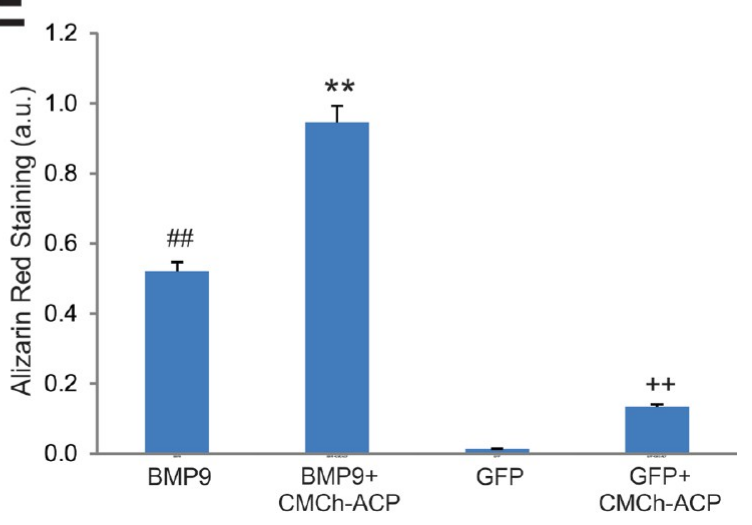

Figure 5. CMCh-ACP hybrid gel is osteoinductive and augments BMP9-induced alkaline phosphatase (ALP) activity and matrix mineralization of MSCs. (A) iMADs cells infected with Ad-GFP or Ad-BMP9 were plated into 24 well plates with or without CMCh-ACP hybrid gel. GFP signal was recorded at 2 days after plating. (B) Qualitative histochemical staining of ALP activity was carried out on day 5. Representative results are shown. (C) Quantitative ALP activity was determined at 3, 5, and 7 days after infection. All assays were done in triplicate. (D) Alizarin Red S staining was carried out after the infected cells were cultured in mineralization medium for 7 days. Representative results are shown. (E) The Alizarin Red S staining was quantitatively analyzed using the ImageJ program. "\#\#” $p<0.01$, compared with that of the GFP only group; “**” $p<0.01$, compared with that of the BMP9 only group; "++" $p<0.01$, compared with that of the GFP only group.

by the unfriendly environment, we reinfected the iMADs cells with another dose of adenovirus and found that the RFP signal could be restored to certain extents, suggesting that most of the cells may be still viable (Figure 3B). More quantitative GLuc analysis revealed that the GLuc activities remained at relatively steady levels until 15 days after seeding (Figure 3C).

Furthermore, we conducted SEM analysis to determine the cell morphology and mineralization on the surface and inside of the CMCh-ACP hybrid gel. Compared with the hydrogel without any iMADs adhered to (Figure 4A), the AdBMP9infected iMADs cells (Figure 4B) were found well attached to the outside surface, and the interior surface of the CMCh-ACP hydrogel and mineralized nodules could be easily identified (Figure 4C). Collectively, the above results suggest that the CMCh-ACP hybrid gel may provide a biocompatible and cellfriendly scaffold environment for mesenchymal stem cell based bone formation.
3.4. CMCh-ACP Hybrid Gel Is Osteoinductive and Promotes BMP9-Induced Osteogenic Differentiation in Vitro. We next sought to assess the effect of CMCh-ACP hybrid nanoparticles on osteogenic differentiation in the presence and absence of BMP9. We previously showed that BMP9 is the most potent bone-forming factor. ${ }^{2,3,19,20,70}$ We effectively transduced the iMADs with Ad-BMP9 or Ad-GFP and coseeded the cells with the CMCh-ACP hydrogel (Figure 5A). At day 5, the GFPinfected iMADs coseeded with the CMCh-ACP hybrid gel exhibited readily detectable alkaline phosphatase (ALP) activity, compared with that of GFP-infected iMADs only, while BMP9regulated ALP activity was augmented by coplating with the CMCh-ACP hybrid gel (Figure 5B). Similarly, the quantitative ALP assay further confirmed that the CMCh-ACP hybrid gel effectively augmented BMP9-induced ALP activity at all tested time points, while the CMCh-ACP hybrid gel alone induced significantly detectable ALP activities (Figure 5C). 


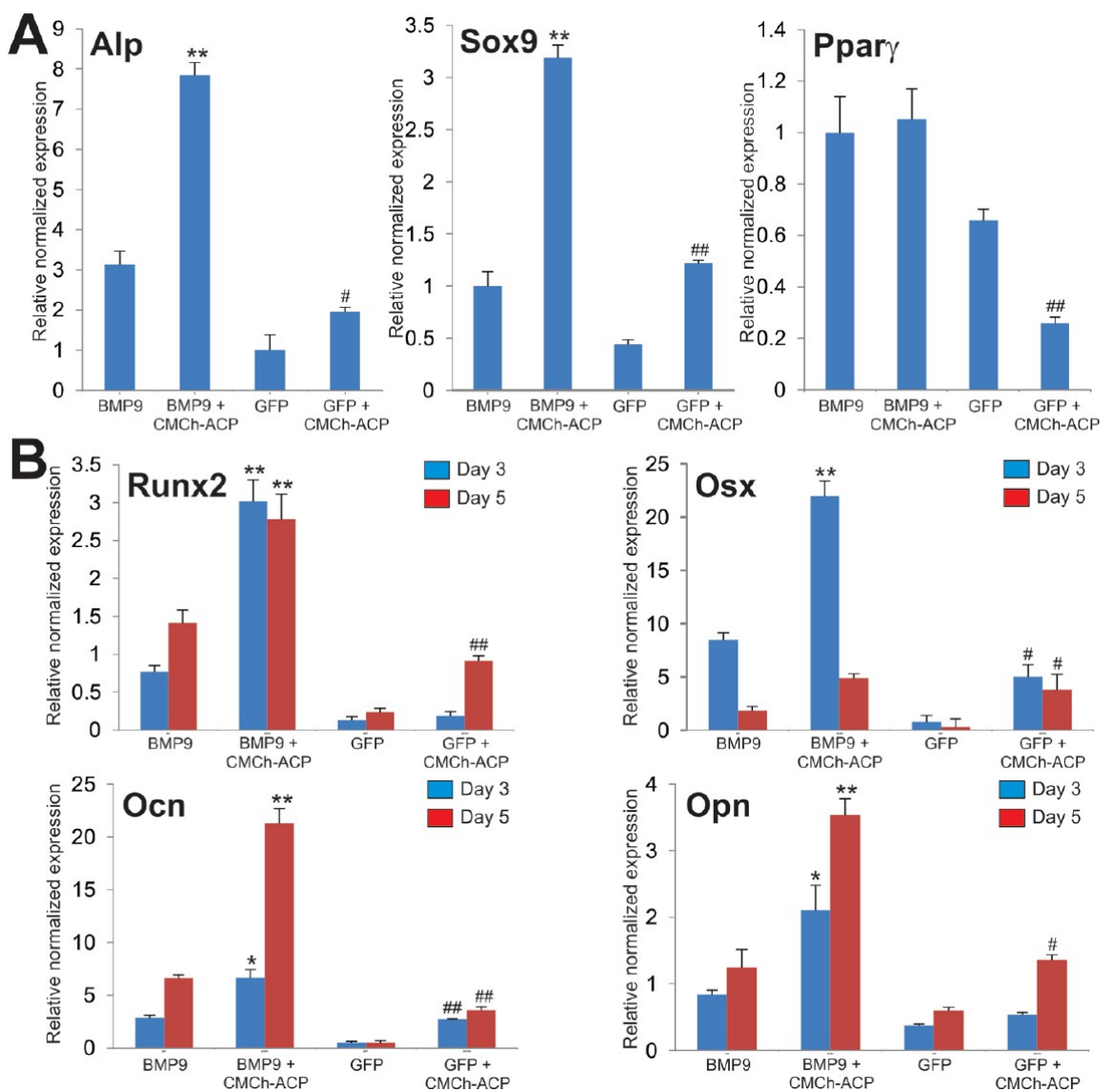

Figure 6. CMCh-ACP hybrid gel promotes BMP9-induced osteogenic and chondrogenic markers. (A) CMCh-ACP hybrid gel enhances BMP9induced expression of Alp and Sox9 but not Ppary. The iMADs cells infected with Ad-GFP or Ad-BMP9 were plated with or without CMCh-ACP hybrid gel. At $72 \mathrm{~h}$ after plating, total RNA was isolated and subjected to qPCR analysis with primers for mouse Alp, Sox9, and Ppar $\gamma$. (B) CMCh-ACP hybrid gel augments BMP9-induced expression of osteogenic regulators and markers. The iMADs cells infected with Ad-GFP or Ad-BMP9 were plated with or without CMCh-ACP hybrid gel. At 3 or 5 days after plating, total RNA was isolated and subjected to qPCR analysis with primers for mouse Runx2, Osx, Ocn, and Opn. Gapdh was used as a reference gene. Reactions were done in triplicate. "*” $p<0.05$ and “**” $p<0.01$ when compared with that of the BMP9 only groups. "\#” $p<0.05$ and “\#\#" $p<0.01$ when compared with that of the GFP only groups.

We also analyzed the effect of CMCh-ACP hybrid nanoparticles on matrix mineralization of late-stage osteogenesis in vitro. When Ad-GFP or Ad-BMP9 infected iMADs were coplated with or without the CMCh-ACP hybrid gel and maintained in mineralization medium for 7 days, the CMChACP gel alone was shown to induce the formation of mineralization nodules, while BMP9-induced matrix mineralization was significantly potentiated when coplated with the CMCh-ACP hybrid gel (Figure 5D,E). Collectively, the above in vitro results suggest that the CMCh-ACP hybrid gel may be osteoinductive and act synergistically with BMP9 in inducing osteoblastic differentiation of MSCs.

To further confirm the above results at the molecular level, we analyzed the expression of MSC lineage regulators and bonespecific markers in the presence or absence of the CMCh-ACP hybrid gel. As expected, Alp expression was induced by $\mathrm{CMCh}$ ACP $(p<0.05)$ and significantly elevated in the presence of both BMP9 and CMCh-APC gel (Figure 6A). Interestingly, the expression of chondrogenic regulator Sox 9 was induced by CMCh-ACP and/or BMP9 in a similar fashion, while CMChACP did not induce the expression of adipogenic regulator Ppary but rather inhibited BMP9-induced Ppary expression (Figure 6A). Similarly, the CMCh-ACP hybrid gel was shown to upregulate the expression of Runx2 and Osterix (Osx) and augmented BMP9-regulated Runx2 and Osx expression in MSCs
(Figure 6B). Furthermore, the $\mathrm{CMCh}-\mathrm{ACP}$ hybrid gel upregulated the late bone markers $O c n$ and $O p n$ and enhanced BMP9-induced Ocn and Opn expression in MSCs (Figure 6B). Thus, these results indicate that the CMCh-ACP hybrid gel is osteoinductive and enhances BMP9-induced osteogenesis, possibly through upregulation of osteogenic regulators and bone markers.

3.5. CMCh-ACP Hybrid Gel Acts Synergistically with BMP9 and Induces More Uniformly Mineralized Ectopic Bone Regeneration. We further analyzed the in vivo behavior of the CMCh-ACP hybrid gel as a scaffold in the context of BMP9-transduced MSCs. The iMADs cells were infected with Ad-BMP9 or Ad-GFP and then mixed with the CMCh-ACP hybrid gel. The cell-gel mix was injected subcutaneously into the flanks of nude mice. At 4, 6, and 8 weeks after injection, ectopic bone masses were readily recovered from the BMP9 only group and the BMP9 + CMCh-ACP group, while no masses were detectable in the GFP only group or the GFP + CMCh$\mathrm{ACP}$ group at all time points. Interestingly, the masses recovered from the BMP9 + CMCh-ACP group showed rather extensive vascularization on the surface of the masses, compared with that of the masses retrieved from the BMP9 only group (Figure 7A, panel a; Figure S3). When the retrieved masses were subjected to $\mu \mathrm{CT}$ analysis, we found the masses recovered from the BMP9 + CMCh-ACP group exhibited more efficient and more uniform 

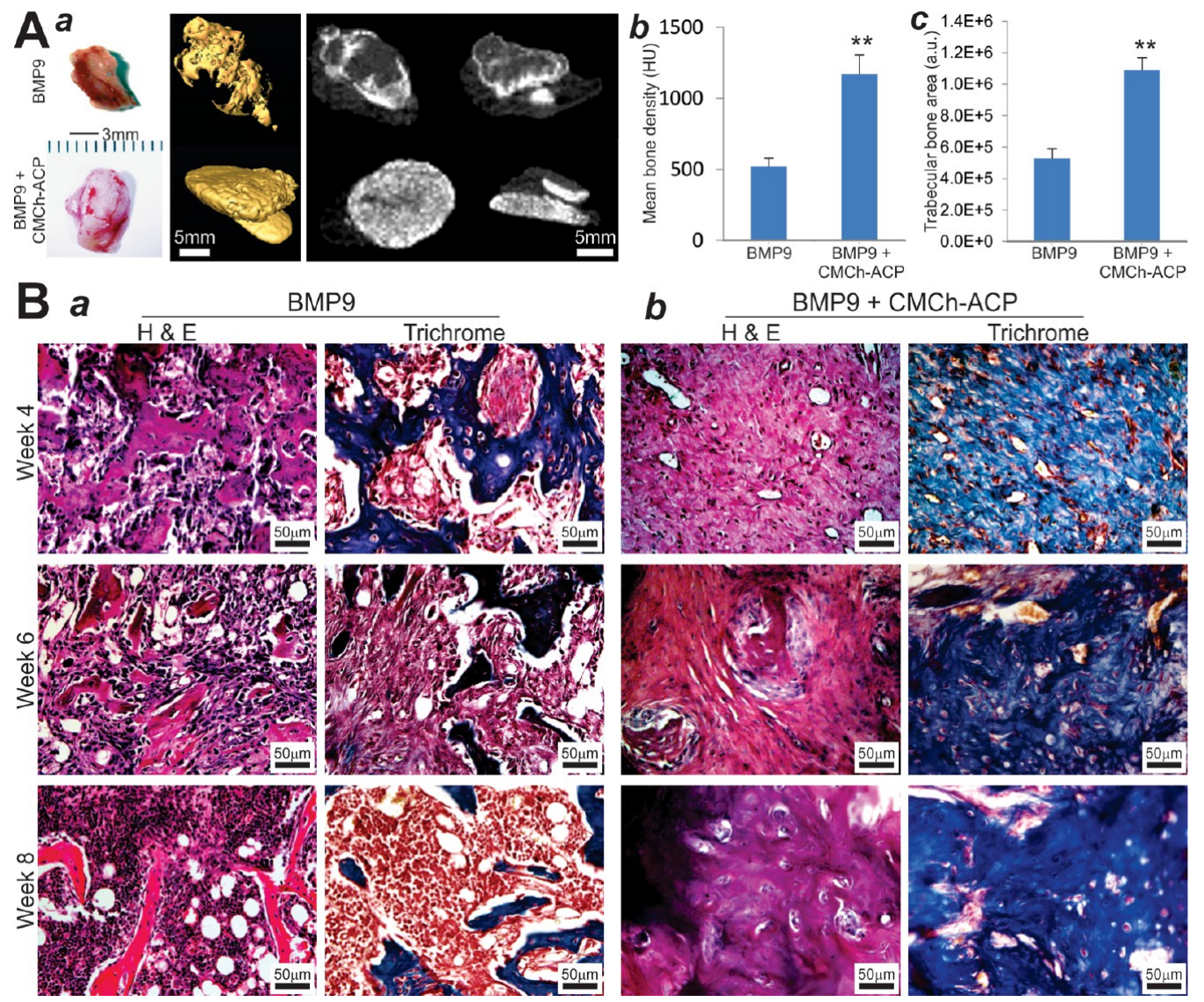

Figure 7. CMCh-ACP hybrid gel acts synergistically with BMP9 and induces more uniformly mineralized ectopic bone formation. (A) Representative images of the subcutaneous masses retrieved at 6 weeks after injection (a). Vascular ingrowth was easily detected inside and outside of the masses retrieved from the BMP9 + CMCh-ACP group. No detectable masses were retrieved from the GFP control or CMCh-ACP only group. The retrieved masses were subjected to micro-CT $(\mu \mathrm{CT})$ imaging and 3D reconstruction (a). Representative images are shown. The $\mu \mathrm{CT}$ data were further analyzed by using Amir software to determine the mean bone density (b) and trabecular bone area (c). “**” $p<0.01$ when compared with that of the BMP9 only group. HU, Hounsfield unit; a.u., arbitrary unit. (B) Hematoxylin and eosin staining and trichrome mineralization staining of the retrieved bone masses from the BMP9 only groups (a) and the BMP9 + CMCh-ACP hybrid gel groups (b) at weeks 4, 6, and 8. Representative images are shown.

bone formation, compared with that of the BMP9 only group (Figure 7A, panel a), which was also confirmed by the quantitative analyses of mean bone density and average trabecular bone area (Figure 7A, panels $\mathrm{b}$ and $\mathrm{c}$ ).

$\mathrm{H} \& \mathrm{E}$ histological analysis revealed that, at the three time points, the masses retrieved from the BMP9 + CMCh-ACP group exhibited a more uniformly distributed, rather dense, and cancellous bone-like phenotype, while the masses recovered from the BMP9 only group showed sparsely distributed trabecular bone formation at the peripheral of the masses as most of the central region remained as undifferentiated or poorly differentiated iMADs cells (Figure $7 \mathrm{~B}$, panel a vs b). Interestingly, the average bone area in the BMP9 only group seemingly peaked at week 4 , gradually decreased, and became sparsely distributed at week 8 (Figure $7 \mathrm{~B}$, panel a), which indicates that bone resorption might have been initiated in these ectopic bone masses at later time points. On the contrary, the masses recovered from the BMP9 + CMCh-ACP hybrid gel group contained a dense and rather mature osteoid matrix (Figure 7B, panel b), suggesting that the CMCh-ACP hybrid gel scaffold may significantly enhance the efficiency and maturity of BMP9-promoted osteogenesis while suppressing the bone resorption process.

Trichrome staining analysis further confirmed the drastic difference in the bone maturity and mineralization status of the
BMP9-initiated bone formation in the presence and absence of the CMCh-ACP hybrid scaffold. In the presence of the CMChACP scaffold, BMP9 induced the formation of robust and well mineralized trabecular bone, which is in sharp contrast to that of the BMP9 only group (Figure 7B, panel a vs b). Collectively, the in vivo findings strongly indicate that the $\mathrm{CMCh}-\mathrm{ACP}$ hybrid gel provided an ideal scaffold for effective bone formation induced by BMP9 while inhibiting the bone resorption process that may occur in the extended period of ectopic osteogenesis.

\section{DISCUSSION}

To search for ideal scaffold materials for effective progenitorbased bone regeneration, we have developed the CMCh-ACP hybrid nanoparticle gel and characterized the physical and structural features of this $\mathrm{pH}$-sensitive hydrogel. We have shown that the CMCh-ACP hydrogel exhibits excellent biocompatibility by supporting MSC proliferation and cell adhesion and that the hydrogel itself is osteoinductive and able to induce osteogenic regulators and bone markers in vitro. Furthermore, the CMCh-ACP hydrogel scaffold significantly promotes the efficiency and mineralization of BMP9-promoted bone regeneration, while suppressing the bone resorption process in the long-term ectopic osteogenesis model. Thus, the $\mathrm{pH}$-sensitive CMCh-ACP hydrogel may be further developed as a novel scaffold for effective MSC-based bone tissue regeneration. 
Amorphous calcium phosphate (ACP) is an important mineral phase produced in mineralized tissues. ${ }^{30-32}$ Biogenic ACP can be found in many tissues, such as the embryonic shark's inner ear, mammalian milk, and dental enamel. ${ }^{30}$ Among all forms of calcium phosphates, ACP is unique because it lacks long-range periodic atomic-scale order of crystalline calcium phosphates. ${ }^{31}$ Unless being kept in dry conditions or doped by stabilizers, ACP is thermodynamically unstable and spontaneously transforms to crystalline calcium orthophosphates, mostly calcium apatites. ${ }^{30}$ Due to its solution instability and easy transformation to crystalline phases, ACP plays an important role in in matrix biomineralization during skeletal calcification. It has been indeed shown that ACP has better osteoconductivity and biodegradability than tricalcium phosphate and hydroxyapatite in vivo. ${ }^{31}$ Thus, given its high chemical and structural similarities with calcified mammalian tissues and favorable biocompatibility and bioresorbability, ACP is considered a promising candidate for bone and tooth tissue engineering. Furthermore, ACP may be used as a remineralizing agent as it has been recently reported that ACP-filled bioactive composites exhibited strong anti-demineralizing/remineralizing effects for the preservation and repair of tooth structures. ${ }^{30-32}$

Chitosan can be easily carboxymethylated, resulting in carboxymethyl chitosan (CMCh), to improve its solubility in aqueous media while its biodegradability and biocompatibility are preserved. ${ }^{35}$ In fact, CMCh exhibits significantly improved solubility in aqueous solution. ${ }^{35}$ Therefore, CMCh-based materials should have numerous applications in the development of biomedical nanodevices and controlled release drug formulations, as well as in various tissue engineering applications including skin, bone, cartilage, liver, nerve, and blood vessel, owing to their porous structures, gel-forming properties, ease of chemical modifications, and high affinity to in vivo macromolecules. 35

In this study, we utilized commonly used carboxymethyl chitosan ( $\mathrm{CMCh}$ ) to stabilize ACP and developed a $\mathrm{pH}$ triggered self-assembled CMCh-ACP composite hydrogel. It should be pointed out that our work represents the first example of using the CMCh-ACP nanoparticles to create an injectable hybrid hydrogel. We are also the first to report that the controlled assembly of the polymer-stabilized ACP nanoparticles to form elastic hydrogels can be accomplished by $\mathrm{pH}$ changes. We have demonstrated that this hydrogel is osteoinductive in vitro and osteoconductive in vivo. The CMCh-ACP hydrogel scaffold has been shown to promote more uniformly mineralized and more mature bone formation induced by BMP9 while inhibiting bone resorption that usually occurs during the extended ectopic osteogenesis.

\section{CONCLUSIONS}

In search of optimal scaffold materials for effective progenitorbased bone regeneration, we developed and characterized the $\mathrm{pH}$-sensitive CMCh-ACP hybrid nanoparticle gel. We demonstrated that the CMCh-ACP hydrogel exhibited excellent biocompatibility and supported MSC proliferation and cell adhesion. The hydrogel itself was osteoinductive and able to induce osteogenic regulators and bone markers in vitro. Furthermore, the CMCh-ACP hydrogel scaffold significantly enhanced the efficiency and maturity of BMP9-initiated bone regeneration, while suppressing the bone resorption process in the long-term ectopic osteogenesis model. Collectively, our results suggest that the $\mathrm{pH}$-sensitive $\mathrm{CMCh}-\mathrm{ACP}$ composite hydrogel may be further developed as a novel scaffold for osteoprogenitor-cell-based bone tissue engineering.

\section{ASSOCIATED CONTENT}

\section{Supporting Information}

The Supporting Information is available free of charge on the ACS Publications website at DOI: 10.1021/acsami.8b19094.

List of TqPCR primers; rheological measurements of $\mathrm{pH}$ induced self-assembly, shear-thinning behavior, and selfhealing characteristics of CMCh-ACP hybrid hydrogels; cytotoxicity and cell proliferation of the iMADs cells entrapped in CMCh-ACP hybrid gel; vascularization feature of the ectopic bone masses retrieved from the $\mathrm{BMP} 9+\mathrm{CMCh}-\mathrm{ACP}$ group (PDF)

\section{AUTHOR INFORMATION}

\section{Corresponding Authors}

*E-mail: huangwei68@263.net. Tel/Fax: (86) 23-89011212 (W.H.).

*E-mail: depablo@uchicago.edu (J.J.d.P).

*E-mail: tche@uchicago.edu. Tel: (773) 702-7169. Fax: (773) 834-4598 (T.-C.H.).

\section{ORCID}

Tong-Chuan He: 0000-0001-7721-3934

\section{Author Contributions}

${ }^{\#}$ C.Z. and N.T.Q. have equal contributions.

\section{Author Contributions}

T.-C.H., J.J.d.P., N.T.Q., C.Z., M.S., M.T., and W.H. conceived and designed the study. C.Z., N.T.Q., M.S., Z.Z., S.H., L.Z., Y.F., and W.Li. performed most experiments and collected data. B.H., A.L.D.L.L., B.Z., Z.D., Y.S., X.W., W.Lu., B.L., Y.L., Z.Y., L.Z., D.C., L.Y., and X.C. provided essential experimental materials (such as adenovirus construction and high titer amplification) and assisted in SEM sample preparation and analysis, histological preparations, immune-staining, and qPCR data analysis and interpretations. T.-C.H., C.Z., N.T.Q., M.T., J.J.d.P., W.H., R.R.R., J.M.W., M.J.L., and A.A. drafted and read the manuscript. All authors reviewed and approved the manuscript.

\section{Notes}

The authors declare no competing financial interest.

\section{ACKNOWLEDGMENTS}

The reported work was supported in part by research grants from the National Key Research and Development Program of China (2016YFC1000803), the National Institutes of Health (CA226303 and DE020140 to T.-C.H. and R.R.R.), the U.S. Department of Defense (OR130096 to J.M.W.), the Scoliosis Research Society (T.-C.H. and M.J.L.), the NIST CHiMAD (70NANB14H012 to M.T. and J.J.d.P.), and the National Natural Science Foundation of China (\#81371972 and \#81572142 to W.H.). This project was also supported in part by The University of Chicago Cancer Center Support Grant (P30CA014599) and the National Center for Advancing Translational Sciences of the National Institutes of Health through Grant Number UL1 TR000430. T.-C.H. was supported by the Mabel Green Myers Research Endowment Fund and The University of Chicago Orthopaedic Surgery Alumni Fund. In addition, the reported work utilized The University of Chicago's MRSEC Facilities, which were supported by the National Science Foundation (\# NSF-DMR-1420709). 


\section{REFERENCES}

(1) Shrivats, A. R.; McDermott, M. C.; Hollinger, J. O. Bone tissue engineering: state of the union. Drug Discovery Today 2014, 19, 781-6.

(2) Deng, Z.-L.; Sharff, K. A.; Tang, N.; Song, W. X.; Luo, J.; Luo, X.; Chen, J.; Bennett, E.; Reid, R.; Manning, D.; Xue, A.; Montag, A. G.; Luu, H. H.; Haydon, R. C.; He, T.-C. Regulation of osteogenic differentiation during skeletal development. Front. Biosci. 2008, 13, 2001-21.

(3) Wang, R. N.; Green, J.; Wang, Z.; Deng, Y.; Qiao, M.; Peabody, M.; Zhang, Q.; Ye, J.; Yan, Z.; Denduluri, S.; Idowu, O.; Li, M.; Shen, C.; Hu, A.; Haydon, R. C.; Kang, R.; Mok, J.; Lee, M. J.; Luu, H. L.; Shi, L. L. Bone Morphogenetic Protein (BMP) signaling in development and human diseases. Genes Dis. 2014, 1, 87-105.

(4) Luo, J.; Sun, M. H.; Kang, Q.; Peng, Y.; Jiang, W.; Luu, H. H.; Luo, Q.; Park, J. Y.; Li, Y.; Haydon, R. C.; He, T. C. Gene therapy for bone regeneration. Curr. Gene Ther. 2005, 5, 167-79.

(5) Pittenger, M. F.; Mackay, A. M.; Beck, S. C.; Jaiswal, R. K.; Douglas, R.; Mosca, J. D.; Moorman, M. A.; Simonetti, D. W.; Craig, S.; Marshak, D. R. Multilineage potential of adult human mesenchymal stem cells. Science 1999, 284, 143-7.

(6) Rastegar, F.; Shenaq, D.; Huang, J.; Zhang, W.; Zhang, B.-Q.; He, B.-C.; Chen, L.; Zuo, G.-W.; Luo, Q.; Shi, Q.; Wagner, E. R.; Huang, E.; Gao, Y.; Gao, J.-L.; Kim, S. H.; Zhou, J.-Z.; Bi, Y.; Su, Y.; Zhu, G.; Luo, J.; Luo, X.; Qin, J.; Reid, R. R.; Luu, H. H.; Haydon, R. C.; Deng, Z.-L.; He, T.-C. Mesenchymal stem cells: Molecular characteristics and clinical applications. World J. Stem Cells 2010, 2, 67-80.

(7) Shenaq, D. S.; Rastegar, F.; Petkovic, D.; Zhang, B.-Q.; He, B.-C.; Chen, L.; Zuo, G.-W.; Luo, Q.; Shi, Q.; Wagner, E. R.; Huang, E.; Gao, Y.; Gao, J.-L.; Kim, S. H.; Yang, K.; Bi, Y.; Su, Y.; Zhu, G.; Luo, J.; Luo, X.; Qin, J.; Reid, R. R.; Luu, H. H.; Haydon, R. C.; He, T.-C. Mesenchymal Progenitor Cells and Their Orthopedic Applications: Forging a Path towards Clinical Trials. Stem Cells Int. 2010, 2010, 519028 .

(8) Zeve, D.; Tang, W.; Graff, J. Fighting fat with fat: the expanding field of adipose stem cells. Cell Stem Cell 2009, 5, 472-81.

(9) Nordberg, R. C.; Loboa, E. G. Our Fat Future: Translating Adipose Stem Cell Therapy. Stem Cells Transl. Med. 2015, 4, 974-9.

(10) Gimble, J. M.; Guilak, F. Differentiation potential of adipose derived adult stem (ADAS) cells. Curr. Top. Dev. Biol. 2003, 58, 13760 .

(11) Raucci, A.; Bellosta, P.; Grassi, R.; Basilico, C.; Mansukhani, A. Osteoblast proliferation or differentiation is regulated by relative strengths of opposing signaling pathways. J. Cell. Physiol. 2008, 215, $442-51$.

(12) Kim, J. H.; Liu, X.; Wang, J.; Chen, X.; Zhang, H.; Kim, S. H.; Cui, J.; Li, R.; Zhang, W.; Kong, Y.; Zhang, J.; Shui, W.; Lamplot, J.; Rogers, M. R.; Zhao, C.; Wang, N.; Rajan, P.; Tomal, J.; Statz, J.; Wu, N.; Luu, H. H.; Haydon, R. C.; He, T.-C. Wnt signaling in bone formation and its therapeutic potential for bone diseases. Ther. Adv. Musculoskeletal Dis. 2013, 5, 13-31.

(13) Yang, K.; Wang, X.; Zhang, H.; Wang, Z.; Nan, G.; Li, Y.; Zhang, F.; Mohammed, M. K.; Haydon, R. C.; Luu, H. H.; Bi, Y.; He, T.-C. The evolving roles of canonical WNT signaling in stem cells and tumorigenesis: implications in targeted cancer therapies. Lab. Invest. 2016, 96, 116-36.

(14) Denduluri, S. K.; Idowu, O.; Wang, Z.; Liao, Z.; Yan, Z.; Mohammed, M. K.; Ye, J.; Wei, Q.; Wang, J.; Zhao, L.; Luu, H. H. Insulin-like growth factor (IGF) signaling in tumorigenesis and the development of cancer drug resistance. Genes Dis. 2015, 2, 13-25.

(15) Teven, C. M.; Farina, E. M.; Rivas, J.; Reid, R. R. Fibroblast growth factor (FGF) signaling in development and skeletal diseases. Genes Dis. 2014, 1, 199-213.

(16) Guruharsha, K. G.; Kankel, M. W.; Artavanis-Tsakonas, S. The Notch signalling system: recent insights into the complexity of a conserved pathway. Nat. Rev. Genet. 2012, 13, 654-66.

(17) Cheng, H.; Jiang, W.; Phillips, F. M.; Haydon, R. C.; Peng, Y.; Zhou, L.; Luu, H. H.; An, N.; Breyer, B.; Vanichakarn, P.; Szatkowski, J. P.; Park, J. Y.; He, T.-C. Osteogenic activity of the fourteen types of human bone morphogenetic proteins (BMPs). J. Bone Joint Surg. Am. 2003, 85-A, 1544-52.

(18) Kang, Q.; Sun, M. H.; Cheng, H.; Peng, Y.; Montag, A. G.; Deyrup, A. T.; Jiang, W.; Luu, H. H.; Luo, J.; Szatkowski, J. P.; Vanichakarn, P.; Park, J. Y.; Li, Y.; Haydon, R. C.; He, T.-C. Characterization of the distinct orthotopic bone-forming activity of 14 BMPs using recombinant adenovirus-mediated gene delivery. Gene Ther. 2004, 11, 1312-20.

(19) Luther, G.; Wagner, E. R.; Zhu, G.; Kang, Q.; Luo, Q.; Lamplot, J.; Bi, Y.; Luo, X.; Luo, J.; Teven, C.; Shi, Q.; Kim, S. H.; Gao, J.-L.; Huang, E.; Yang, K.; Rames, R.; Liu, X.; Li, M.; Hu, N.; Liu, H.; Su, Y.; Chen, L.; He, B.-C.; Zuo, G.-W.; Deng, Z. L.; Reid, R. R.; Luu, H. H.; Haydon, R. C.; He, T.-C. BMP-9 induced osteogenic differentiation of mesenchymal stem cells: molecular mechanism and therapeutic potential. Curr. Gene Ther. 2011, 11, 229-40.

(20) Lamplot, J. D.; Qin, J.; Nan, G.; Wang, J.; Liu, X.; Yin, L.; Tomal, J.; Li, R.; Shui, W.; Zhang, H.; Kim, S. H.; Zhang, W.; Zhang, J.; Kong, Y.; Denduluri, S.; Rogers, M. R.; Pratt, A.; Haydon, R. C.; Luu, H. H.; Angeles, J.; Shi, L. L.; He, T.-C. BMP9 signaling in stem cell differentiation and osteogenesis. Am. J. Stem Cells 2013, 2, 1-21.

(21) Huang, E.; Zhu, G.; Jiang, W.; Yang, K.; Gao, Y.; Luo, Q.; Gao, J.L.; Kim, S. H.; Liu, X.; Li, M.; Shi, Q.; Hu, N.; Wang, L.; Liu, H.; Cui, J.; Zhang, W.; Li, R.; Chen, X.; Kong, Y.-H.; Zhang, J.; Wang, J.; Shen, J.; Bi, Y.; Statz, J.; He, B.-C.; Luo, J.; Wang, H.; Xiong, F.; Luu, H. H.; Haydon, R. C.; Yang, L.; He, T.-C. Growth hormone synergizes with BMP9 in osteogenic differentiation by activating the JAK/STAT/IGF1 pathway in murine multilineage cells. J. Bone Miner. Res. 2012, 27, $1566-75$.

(22) Liao, J.; Yu, X.; Hu, X.; Fan, J.; Wang, J.; Zhang, Z.; Zhao, C.; Zeng, Z.; Shu, Y.; Zhang, R.; Yan, S.; Li, Y.; Zhang, W.; Cui, J.; Ma, C.; Li, L.; Yu, Y.; Wu, T.; Wu, X.; Lei, J.; Wang, J.; Yang, C.; Wu, K.; Wu, Y.; Tang, J.; He, B.-C.; Deng, Z. L.; Luu, H. H.; Haydon, R. C.; Reid, R. R.; Lee, M. J.; Wolf, J. M.; Huang, W.; He, T.-C. lncRNA H19 mediates BMP9-induced osteogenic differentiation of mesenchymal stem cells (MSCs) through Notch signaling. Oncotarget 2017, 8, 53581-53601.

(23) Chen, L.; Jiang, W.; Huang, J.; He, B. C.; Zuo, G. W.; Zhang, W.; Luo, Q.; Shi, Q.; Zhang, B.-Q.; Wagner, E. R.; Luo, J.; Tang, M.; Wietholt, C.; Luo, X.; Bi, Y.; Su, Y.; Liu, B.; Kim, S. H.; He, C. J.; Hu, Y.; Shen, J.; Rastegar, F.; Huang, E.; Gao, Y.; Gao, J. L.; Zhou, J. Z.; Reid, R. R.; Luu, H. H.; Haydon, R. C.; He, T.-C.; Deng, Z.-L. Insulin-like growth factor 2 (IGF-2) potentiates BMP-9-induced osteogenic differentiation and bone formation. J. Bone Miner. Res. 2010, 25, 2447-59.

(24) Zhang, W.; Deng, Z. L.; Chen, L.; Zuo, G.-W.; Luo, Q.; Shi, Q.; Zhang, B. Q.; Wagner, E. R.; Rastegar, F.; Kim, S. H.; Jiang, W.; Shen, J.; Huang, E.; Gao, Y.; Gao, J.-L.; Zhou, J.-Z.; Luo, J.; Huang, J.; Luo, X.; Bi, Y.; Su, Y.; Yang, K.; Liu, H.; Luu, H. H.; Haydon, R. C.; He, T.-C.; He, B.-C. Retinoic acids potentiate BMP9-induced osteogenic differentiation of mesenchymal progenitor cells. PLoS One 2010, 5, No. e11917.

(25) Hu, N.; Jiang, D.; Huang, E.; Liu, X.; Li, R.; Liang, X.; Kim, S. H.; Chen, X.; Gao, J.-L.; Zhang, H.; Zhang, W.; Kong, Y.-H.; Zhang, J.; Wang, J.; Shui, W.; Luo, X.; Liu, B.; Cui, J.; Rogers, M. R.; Shen, J.; Zhao, C.; Wang, N.; Wu, N.; Luu, H. H.; Haydon, R. C.; He, T.-C.; Huang, W. BMP9-regulated angiogenic signaling plays an important role in the osteogenic differentiation of mesenchymal progenitor cells. J. Cell Sci. 2013, 126, 532-41.

(26) Liu, X.; Qin, J.; Luo, Q.; Bi, Y.; Zhu, G.; Jiang, W.; Kim, S. H.; Li, M.; Su, Y.; Nan, G.; Cui, J.; Zhang, W.; Li, R.; Chen, X.; Kong, Y.; Zhang, J.; Wang, J.; Rogers, M. R.; Zhang, H.; Shui, W.; Zhao, C.; Wang, N.; Liang, X.; Wu, N.; He, Y.; Luu, H. H.; Haydon, R. C.; Shi, L. L.; Li, T.; He, T. C.; Li, M. Cross-talk between EGF and BMP9 signalling pathways regulates the osteogenic differentiation of mesenchymal stem cells. J. Cell Mol. Med. 2013, 17, 1160-72.

(27) Zhang, H.; Wang, J.; Deng, F.; Huang, E.; Yan, Z.; Wang, Z.; Deng, Y.; Zhang, Q.; Zhang, Z.; Ye, J.; Qiao, M.; Li, R.; Wang, J.; Wei, Q.; Zhou, G.; Luu, H. H.; Haydon, R. C.; He, T.-C.; Deng, F. Canonical Wnt signaling acts synergistically on BMP9-induced osteo/odonto- 
blastic differentiation of stem cells of dental apical papilla (SCAPs). Biomaterials 2015, 39, 145-54.

(28) Liao, J.; Wei, Q.; Zou, Y.; Fan, J.; Song, D.; Cui, J.; Zhang, W.; Zhu, Y.; Ma, C.; Hu, X.; Qu, X.; Chen, L.; Yu, X.; Zhang, Z.; Wang, C.; Zhao, C.; Zeng, Z.; Zhang, R.; Yan, S.; Wu, T.; Wu, X.; Shu, Y.; Lei, J.; Li, Y.; Luu, H. H.; Lee, M. J.; Reid, R. R.; Ameer, G. A.; Wolf, J. M.; He, T.-C.; Huang, W. Notch Signaling Augments BMP9-Induced Bone Formation by Promoting the Osteogenesis-Angiogenesis Coupling Process in Mesenchymal Stem Cells (MSCs). Cell Physiol. Biochem. 2017, 41, 1905-1923.

(29) Bose, S.; Roy, M.; Bandyopadhyay, A. Recent advances in bone tissue engineering scaffolds. Trends Biotechnol. 2012, 30, 546-54.

(30) Dorozhkin, S. V. Amorphous calcium (ortho)phosphates. Acta Biomater. 2010, 6, 4457-75.

(31) Zhao, J.; Liu, Y.; Sun, W.-b.; Zhang, H. Amorphous calcium phosphate and its application in dentistry. Chem. Cent. J. 2011, 5, 40.

(32) Bienek, D. R.; Skrtic, D. Utility of Amorphous Calcium Phosphate-Based Scaffolds in Dental/Biomedical Applications. Biointerface Res. Appl. Chem. 2017, 7, 1989-1994.

(33) Prabaharan, M.; Mano, J. F. Chitosan-based particles as controlled drug delivery systems. Drug Delivery 2005, 12, 41-57.

(34) Bhattarai, N.; Gunn, J.; Zhang, M. Chitosan-based hydrogels for controlled, localized drug delivery. Adv. Drug Delivery Rev. 2010, 62, 83-99.

(35) Fonseca-Santos, B.; Chorilli, M. An overview of carboxymethyl derivatives of chitosan: Their use as biomaterials and drug delivery systems. Mater. Sci. Eng., C 2017, 77, 1349-1362.

(36) Wu, N.; Zhang, H.; Deng, F.; Li, R.; Zhang, W.; Chen, X.; Wen, S.; Wang, N.; Zhang, J.; Yin, L.; Liao, Z.; Zhang, Z.; Zhang, Q.; Yan, Z.; Liu, W.; Wu, D.; Ye, J.; Deng, Y.; Yang, K.; Luu, H. H.; Haydon, R. C.; He, T.-C. Overexpression of Ad5 precursor terminal protein accelerates recombinant adenovirus packaging and amplification in HEK-293 packaging cells. Gene Ther. 2014, 21, 629-37.

(37) Wei, Q.; Fan, J.; Liao, J.; Zou, Y.; Song, D.; Liu, J.; Cui, J.; Liu, F.; Ma, C.; Hu, X.; Li, L.; Yu, Y.; Qu, X.; Chen, L.; Yu, X.; Zhang, Z.; Zhao, C.; Zeng, Z.; Zhang, R.; Yan, S.; Wu, X.; Shu, Y.; Reid, R. R.; Lee, M. J.; Wolf, J. M.; He, T.-C. Engineering the Rapid Adenovirus Production and Amplification (RAPA) Cell Line to Expedite the Generation of Recombinant Adenoviruses. Cell Physiol. Biochem. 2017, 41, 23832398.

(38) Lu, S.; Wang, J.; Ye, J.; Zou, Y.; Zhu, Y.; Wei, Q.; Wang, X.; Tang, S.; Liu, H.; Fan, J.; Zhang, F.; Farina, E. M.; Mohammed, M. M.; Song, D.; Liao, J.; Huang, J.; Guo, D.; Lu, M.; Liu, F.; Liu, J.; Li, L.; Ma, C.; Hu, X.; Lee, M. J.; Reid, R. R.; Ameer, G. A.; Zhou, D.; He, T. Bone morphogenetic protein 9 (BMP9) induces effective bone formation from reversibly immortalized multipotent adipose-derived (iMAD) mesenchymal stem cells. Am. J. Transl. Res. 2016, 8, 3710-3730.

(39) Huang, E.; Bi, Y.; Jiang, W.; Luo, X.; Yang, K.; Gao, J.-L.; Gao, Y.; Luo, Q.; Shi, Q.; Kim, S. H.; Liu, X.; Li, M.; Hu, N.; Liu, H.; Cui, J.; Zhang, W.; Li, R.; Chen, X.; Shen, J.; Kong, Y.; Zhang, J.; Wang, J.; Luo, J.; He, B.-C.; Wang, H.; Reid, R. R.; Luu, H. H.; Haydon, R. C.; Yang, L.; He, T.-C. Conditionally immortalized mouse embryonic fibroblasts retain proliferative activity without compromising multipotent differentiation potential. PLoS One 2012, 7, No. e32428.

(40) Yu, X.; Chen, L.; Wu, K.; Yan, S.; Zhang, R.; Zhao, C.; Zeng, Z.; Shu, Y.; Huang, S.; Lei, J.; Ji, X.; Yuan, C.; Zhang, L.; Feng, Y.; Liu, W.; Huang, B.; Zhang, B.; Luo, W.; Wang, X.; Liu, B.; Haydon, R. C.; Luu, H. H.; He, T.-C.; Gan, H. Establishment and functional characterization of the reversibly immortalized mouse glomerular podocytes (imPODs). Genes Dis. 2018, 5, 137-149.

(41) Zeng, Z.; Huang, B.; Huang, S.; Zhang, R.; Yan, S.; Yu, X.; Shu, Y.; Zhao, C.; Lei, J.; Zhang, W.; Yang, C.; Wu, K.; Wu, Y.; An, L.; Ji, X.; Gong, C.; Yuan, C.; Zhang, L.; Liu, W.; Feng, Y.; Zhang, B.; Dai, Z.; Shen, Y.; Wang, X.; Luo, W.; Haydon, R. C.; Luu, H. H.; Zhou, L.; Reid, R. R.; He, T.-C.; Wu, X. The development of a sensitive fluorescent protein-based transcript reporter for high throughput screening of negative modulators of lncRNAs. Genes Dis. 2018, 5, 62-74.

(42) Luo, J.; Deng, Z.-L.; Luo, X.; Tang, N.; Song, W.-X.; Chen, J.; Sharff, K. A.; Luu, H. H.; Haydon, R. C.; Kinzler, K. W.; Vogelstein, B.;
He, T.-C. A protocol for rapid generation of recombinant adenoviruses using the AdEasy system. Nat. Protoc. 2007, 2, 1236-47.

(43) Kang, Q.; Song, W.-X.; Luo, Q.; Tang, N.; Luo, J.; Luo, X.; Chen, J.; Bi, Y.; He, B.-C.; Park, J. K.; Jiang, W.; Tang, Y.; Huang, J.; Su, Y.; Zhu, G.-H.; He, Y.; Yin, H.; Hu, Z.; Wang, Y.; Chen, L.; Zuo, G.-W.; Pan, X.; Shen, J.; Vokes, T.; Reid, R. R.; Haydon, R. C.; Luu, H. H.; He, T.-C. A comprehensive analysis of the dual roles of BMPs in regulating adipogenic and osteogenic differentiation of mesenchymal progenitor cells. Stem Cells Dev. 2009, 18, 545-58.

(44) Li, R.; Yan, Z.; Ye, J.; Huang, H.; Wang, Z.; Wei, Q.; Wang, J.; Zhao, L.; Lu, S.; Wang, X.; Tang, S.; Fan, J.; Zhang, F.; Zou, Y.; Song, D.; Liao, J.; Lu, M.; Liu, F.; Shi, L. L.; Athiviraham, A.; Lee, M. J.; He, T. C.; Zhang, Z. The Prodomain-Containing BMP9 Produced from a Stable Line Effectively Regulates the Differentiation of Mesenchymal Stem Cells. Int. J. Med. Sci. 2016, 13, 8-18.

(45) Li, R.; Zhang, W.; Cui, J.; Shui, W.; Yin, L.; Wang, Y.; Zhang, H.; Wang, N.; Wu, N.; Nan, G.; Chen, X.; Wen, S.; Deng, F.; Zhang, H.; Zhou, G.; Liao, Z.; Zhang, J.; Zhang, Q.; Yan, Z.; Liu, W.; Zhang, Z.; Ye, J.; Deng, Y.; Luu, H. H.; Haydon, R. C.; He, T.-C.; Deng, Z.-L. Targeting BMP9-promoted human osteosarcoma growth by inactivation of notch signaling. Curr. Cancer Drug Targets 2014, 14, 274-85.

(46) Tang, N.; Song, W.-X.; Luo, J.; Luo, X.; Chen, J.; Sharff, K. A.; Bi, Y.; He, B.-C.; Huang, J.-Y.; Zhu, G.-H.; Su, Y.-X.; Jiang, W.; Tang, M.; He, Y.; Wang, Y.; Chen, L.; Zuo, G.-W.; Shen, J.; Pan, X.; Reid, R. R.; Luu, H. H.; Haydon, R. C.; He, T.-C. BMP-9-induced osteogenic differentiation of mesenchymal progenitors requires functional canonical Wnt/beta-catenin signalling. J. Cell Mol. Med. 2009, 13, 2448-64.

(47) Zhao, C.; Wu, N.; Deng, F.; Zhang, H.; Wang, N.; Zhang, W.; Chen, X.; Wen, S.; Zhang, J.; Yin, L.; Liao, Z.; Zhang, Z.; Zhang, Q.; Yan, Z.; Liu, W.; Wu, D.; Ye, J.; Deng, Y.; Zhou, G.; Luu, H. H.; Haydon, R. C.; Si, W.; He, T.-C. Adenovirus-mediated gene transfer in mesenchymal stem cells can be significantly enhanced by the cationic polymer polybrene. PLoS One 2014, 9, No. e92908.

(48) He, B.-C.; Gao, J.-L.; Zhang, B.-Q.; Luo, Q.; Shi, Q.; Kim, S. H.; Huang, E.; Gao, Y.; Yang, K.; Wagner, E. R.; Wang, L.; Tang, N.; Luo, J.; Liu, X.; Li, M.; Bi, Y.; Shen, J.; Luther, G.; Hu, N.; Zhou, Q.; Luu, H. H.; Haydon, R. C.; Zhao, Y.; He, T.-C. Tetrandrine inhibits Wnt/betacatenin signaling and suppresses tumor growth of human colorectal cancer. Mol. Pharmacol. 2011, 79, 211-9.

(49) Huang, J.; Bi, Y.; Zhu, G.-H.; He, Y.; Su, Y.; He, B.-C.; Wang, Y.; Kang, Q.; Chen, L.; Zuo, G. W.; Luo, Q.; Shi, Q.; Zhang, B.-Q.; Huang, A.; Zhou, L.; Feng, T.; Luu, H. H.; Haydon, R. C.; He, T.-C.; Tang, N. Retinoic acid signalling induces the differentiation of mouse fetal liverderived hepatic progenitor cells. Liver Int. 2009, 29, 1569-81.

(50) Yu, X.; Liu, F.; Zeng, L.; He, F.; Zhang, R.; Yan, S.; Zeng, Z.; Shu, Y.; Zhao, C.; Wu, X.; Lei, J.; Zhang, W.; Yang, C.; Wu, K.; Wu, Y.; An, L.; Huang, S.; Ji, X.; Gong, C.; Yuan, C.; Zhang, L.; Feng, Y.; Huang, B.; Liu, W.; Zhang, B.; Dai, Z.; Wang, X.; Liu, B.; Haydon, R. C.; Luu, H. H.; Gan, H.; He, T.-C.; Chen, L. Niclosamide Exhibits Potent Anticancer Activity and Synergizes with Sorafenib in Human Renal Cell Cancer Cells. Cell Physiol. Biochem. 2018, 47, 957-971.

(51) Zhang, F.; Li, Y.; Zhang, H.; Huang, E.; Gao, L.; Luo, W.; Wei, Q.; Fan, J.; Song, D.; Liao, J.; Zou, Y.; Liu, F.; Liu, J.; Huang, J.; Guo, D.; Ma, C.; Hu, X.; Li, L.; Qu, X.; Chen, L.; Yu, X.; Zhang, Z.; Wu, T.; Luu, H. H.; Haydon, R. C.; Song, J.; He, T. C.; Ji, P. Anthelmintic mebendazole enhances cisplatin's effect on suppressing cell proliferation and promotes differentiation of head and neck squamous cell carcinoma (HNSCC). Oncotarget 2017, 8, 12968-12982.

(52) Deng, Y.; Zhang, J.; Wang, Z.; Yan, Z.; Qiao, M.; Ye, J.; Wei, Q.; Wang, J.; Wang, X.; Zhao, L.; Lu, S.; Tang, S.; Mohammed, M. K.; Liu, H.; Fan, J.; Zhang, F.; Zou, Y.; Liao, J.; Qi, H.; Haydon, R. C.; Luu, H. H.; He, T.-C.; Tang, L. Antibiotic monensin synergizes with EGFR inhibitors and oxaliplatin to suppress the proliferation of human ovarian cancer cells. Sci Rep. 2015, 5, 17523.

(53) Li, Y.; Wagner, E. R.; Yan, Z.; Wang, Z.; Luther, G.; Jiang, W.; Ye, J.; Wei, Q.; Wang, J.; Zhao, L.; Lu, S.; Wang, X.; Mohammed, M. K.; Tang, S.; Liu, H.; Fan, J.; Zhang, F.; Zou, Y.; Song, D.; Liao, J.; Haydon, R. C.; Luu, H. H.; He, T.-C. The Calcium-Binding Protein S100A6 Accelerates Human Osteosarcoma Growth by Promoting Cell 
Proliferation and Inhibiting Osteogenic Differentiation. Cell Physiol. Biochem. 2015, 37, 2375-92.

(54) Ye, J.; Wang, J.; Zhu, Y.; Wei, Q.; Wang, X.; Yang, J.; Tang, S.; Liu, H.; Fan, J.; Zhang, F.; Farina, E. M.; Mohammed, M. K.; Zou, Y.; Song, D.; Liao, J.; Huang, J.; Guo, D.; Lu, M.; Liu, F.; Liu, J.; Li, L.; Ma, C.; Hu, X.; Haydon, R. C.; Lee, M. J.; Reid, R. R.; Ameer, G. A.; Yang, L.; He, T.-C. A thermoresponsive polydiolcitrate-gelatin scaffold and delivery system mediates effective bone formation from BMP9transduced mesenchymal stem cells. Biomed. Mater. 2016, 11, No. 025021.

(55) Zou, Y.; Qazvini, N. T.; Zane, K.; Sadati, M.; Wei, Q.; Liao, J.; Fan, J.; Song, D.; Liu, J.; Ma, C.; Qu, X.; Chen, L.; Yu, X.; Zhang, Z.; Zhao, C.; Zeng, Z.; Zhang, R.; Yan, S.; Wu, T.; Wu, X.; Shu, Y.; Li, Y.; Zhang, W.; Reid, R. R.; Lee, M. J.; Wolf, J. M.; Tirrell, M.; He, T.-C.; de Pablo, J. J.; Deng, Z.-L. Gelatin-Derived Graphene-Silicate Hybrid Materials Are Biocompatible and Synergistically Promote BMP9Induced Osteogenic Differentiation of Mesenchymal Stem Cells. ACS Appl. Mater. Interfaces 2017, 9, 15922-15932.

(56) Zhao, C.; Zeng, Z.; Qazvini, N. T.; Yu, X.; Zhang, R.; Yan, S.; Shu, Y.; Zhu, Y.; Duan, C.; Bishop, E.; Lei, J.; Zhang, W.; Yang, C.; Wu, K.; Wu, Y.; An, L.; Huang, S.; Ji, X.; Gong, C.; Yuan, C.; Zhang, L.; Liu, W.; Huang, B.; Feng, Y.; Zhang, B.; Dai, Z.; Shen, Y.; Wang, X.; Luo, W.; Oliveira, L.; Athiviraham, A.; Lee, M. J.; Wolf, J. M.; Ameer, G. A.; Reid, R. R.; He, T.-C.; Huang, W. Thermoresponsive Citrate-Based Graphene Oxide Scaffold Enhances Bone Regeneration from BMP9Stimulated Adipose-Derived Mesenchymal Stem Cells. ACS Biomater. Sci. Eng. 2018, 2943.

(57) Gao, Y.; Huang, E.; Zhang, H.; Wang, J.; Wu, N.; Chen, X.; Wang, N.; Wen, S.; Nan, G.; Deng, F.; Liao, Z.; Wu, D.; Zhang, B.; Zhang, J.; Haydon, R. C.; Luu, H. H.; Shi, L. L.; He, T.-C. Crosstalk between Wnt/beta-catenin and estrogen receptor signaling synergistically promotes osteogenic differentiation of mesenchymal progenitor cells. PLoS One 2013, 8, No. e82436.

(58) Wang, N.; Zhang, W.; Cui, J.; Zhang, H.; Chen, X.; Li, R.; Wu, N.; Chen, X.; Wen, S.; Zhang, J.; Yin, L.; Deng, F.; Liao, Z.; Zhang, Z.; Zhang, Q.; Yan, Z.; Liu, W.; Ye, J.; Deng, Y.; Wang, Z.; Qiao, M.; Luu, H. H.; Haydon, R. C.; Shi, L. L.; Liang, H.; He, T.-C. The piggyBac transposon-mediated expression of SV40 T antigen efficiently immortalizes mouse embryonic fibroblasts (MEFs). PLoS One 2014, 9, No. e97316.

(59) Shu, Y.; Yang, C.; Ji, X.; Zhang, L.; Bi, Y.; Yang, K.; Gong, M.; Liu, X.; Guo, Q.; Su, Y.; Qu, X.; Nan, G.; Zhao, C.; Zeng, Z.; Yu, X.; Zhang, R.; Yan, S.; Lei, J.; Wu, K.; Wu, Y.; An, L.; Huang, S.; Gong, C.; Yuan, C.; Liu, W.; Huang, B.; Feng, Y.; Zhang, B.; Dai, Z.; Shen, Y.; Luo, W.; Wang, X.; Haydon, R. C.; Luu, H. H.; Reid, R. R.; Wolf, J. M.; Lee, M.J.; He, T.-C.; Li, Y. Reversibly immortalized human umbilical cord-derived mesenchymal stem cells (UC-MSCs) are responsive to BMP9-induced osteogenic and adipogenic differentiation. J. Cell Biochem. 2018, 8872.

(60) Yan, S.; Zhang, R.; Wu, K.; Cui, J.; Huang, S.; Ji, X.; An, L.; Yuan, C.; Gong, C.; Zhang, L.; Liu, W.; Feng, Y.; Zhang, B.; Dai, Z.; Shen, Y.; Wang, X.; Luo, W.; Liu, B.; Haydon, R. C.; Lee, M. J.; Reid, R. R.; Wolf, J. M.; Shi, Q.; Luu, H. H.; He, T.-C.; Weng, Y. Characterization of the essential role of bone morphogenetic protein 9 (BMP9) in osteogenic differentiation of mesenchymal stem cells (MSCs) through RNA interference. Genes Dis. 2018, 5, 172-184.

(61) Wang, J.; Liao, J.; Zhang, F.; Song, D.; Lu, M.; Liu, J.; Wei, Q.; Tang, S.; Liu, H.; Fan, J.; Zou, Y.; Guo, D.; Huang, J.; Liu, F.; Ma, C.; Hu, X.; Li, L.; Qu, X.; Chen, L.; Weng, Y.; Lee, M. J.; He, T. C.; Reid, R. R.; Zhang, J. NEL-Like Molecule-1 (Nell1) Is Regulated by Bone Morphogenetic Protein 9 (BMP9) and Potentiates BMP9-Induced Osteogenic Differentiation at the Expense of Adipogenesis in Mesenchymal Stem Cells. Cell Physiol. Biochem. 2017, 41, 484-500.

(62) Wang, J.; Zhang, H.; Zhang, W.; Huang, E.; Wang, N.; Wu, N.; Wen, S.; Chen, X.; Liao, Z.; Deng, F.; Yin, L.; Zhang, J.; Zhang, Q.; Yan, Z.; Liu, W.; Zhang, Z.; Ye, J.; Deng, Y.; Luu, H. H.; Haydon, R. C.; He, T.-C.; Deng, F. Bone morphogenetic protein-9 effectively induces osteo/odontoblastic differentiation of the reversibly immortalized stem cells of dental apical papilla. Stem Cells Dev. 2014, 23, 1405-16.
(63) Song, D.; Zhang, F.; Reid, R. R.; Ye, J.; Wei, Q.; Liao, J.; Zou, Y.; Fan, J.; Ma, C.; Hu, X.; Qu, X.; Chen, L.; Li, L.; Yu, Y.; Yu, X.; Zhang, Z.; Zhao, C.; Zeng, Z.; Zhang, R.; Yan, S.; Wu, T.; Wu, X.; Shu, Y.; Lei, J.; Li, Y.; Zhang, W.; Wang, J.; Lee, M. J.; Wolf, J. M.; Huang, D.; He, T.-C. BMP9 induces osteogenesis and adipogenesis in the immortalized human cranial suture progenitors from the patent sutures of craniosynostosis patients. J. Cell Mol. Med. 2017, 21, 2782-2795.

(64) Zhang, Q.; Wang, J.; Deng, F.; Yan, Z.; Xia, Y.; Wang, Z.; Ye, J.; Deng, Y.; Zhang, Z.; Qiao, M.; Li, R.; Denduluri, S. K.; Wei, Q.; Zhao, L.; Lu, S.; Wang, X.; Tang, S.; Liu, H.; Luu, H. H.; Haydon, R. C.; He, T.-C.; Jiang, L. TqPCR: A Touchdown qPCR Assay with Significantly Improved Detection Sensitivity and Amplification Efficiency of SYBR Green qPCR. PLoS One 2015, 10, No. e0132666.

(65) Hu, X.; Li, L.; Yu, X.; Zhang, R.; Yan, S.; Zeng, Z.; Shu, Y.; Zhao, C.; Wu, X.; Lei, J.; Li, Y.; Zhang, W.; Yang, C.; Wu, K.; Wu, Y.; An, L.; Huang, S.; Ji, X.; Gong, C.; Yuan, C.; Zhang, L.; Liu, W.; Huang, B.; Feng, Y.; Zhang, B.; Haydon, R. C.; Luu, H. H.; Reid, R. R.; Lee, M. J.; Wolf, J. M.; Yu, Z.; He, T.-C. CRISPR/Cas9-mediated reversibly immortalized mouse bone marrow stromal stem cells (BMSCs) retain multipotent features of mesenchymal stem cells (MSCs). Oncotarget 2017, 8, 111847-111865.

(66) Fan, J.; Wei, Q.; Liao, J.; Zou, Y.; Song, D.; Xiong, D.; Ma, C.; Hu, X.; Qu, X.; Chen, L.; Li, L.; Yu, Y.; Yu, X.; Zhang, Z.; Zhao, C.; Zeng, Z.; Zhang, R.; Yan, S.; Wu, T.; Wu, X.; Shu, Y.; Lei, J.; Li, Y.; Zhang, W.; Haydon, R. C.; Luu, H. H.; Huang, A.; He, T.-C.; Tang, H. Noncanonical Wnt signaling plays an important role in modulating canonical Wnt-regulated stemness, proliferation and terminal differentiation of hepatic progenitors. Oncotarget 2017, 8, 27105-27119.

(67) Zhao, C.; Jiang, W.; Zhou, N.; Liao, J.; Yang, M.; Hu, N.; Liang, X.; Xu, W.; Chen, H.; Liu, W.; Shi, L. L.; Oliveira, L.; Wolf, J. M.; Ho, S.; Athiviraham, A.; Tsai, H. M.; He, T.-C.; Huang, W. Sox9 augments BMP2-induced chondrogenic differentiation by downregulating Smad7 in mesenchymal stem cells (MSCs). Genes Dis. 2017, 4, 229-239.

(68) Deng, F.; Chen, X.; Liao, Z.; Yan, Z.; Wang, Z.; Deng, Y.; Zhang, Q.; Zhang, Z.; Ye, J.; Qiao, M.; Li, R.; Denduluri, S.; Wang, J.; Wei, Q.; Li, M.; Geng, N.; Zhao, L.; Zhou, G.; Zhang, P.; Luu, H. H.; Haydon, R. C.; Reid, R. R.; Yang, T.; He, T.-C. A simplified and versatile system for the simultaneous expression of multiple siRNAs in mammalian cells using Gibson DNA Assembly. PLoS One 2014, 9, No. e113064.

(69) Su, Y.; Wagner, E. R.; Luo, Q.; Huang, J.; Chen, L.; He, B. C.; Zuo, G. W.; Shi, Q.; Zhang, B. Q.; Zhu, G.; Bi, Y.; Luo, J.; Luo, X.; Kim, S. H.; Shen, J.; Rastegar, F.; Huang, E.; Gao, Y.; Gao, J.-L.; Yang, K.; Wietholt, C.; Li, M.; Qin, J.; Haydon, R. C.; He, T.-C.; Luu, H. H. Insulin-like growth factor binding protein 5 suppresses tumor growth and metastasis of human osteosarcoma. Oncogene 2011, 30, 3907-17.

(70) Zhang, F.; Song, J.; Zhang, H.; Huang, E.; Song, D.; Tollemar, V.; Wang, J.; Wang, J.; Mohammed, M.; Wei, Q.; Fan, J.; Liao, J.; Zou, Y.; Liu, F.; Hu, X.; Qu, X.; Chen, L.; Yu, X.; Luu, H. H.; Lee, M. J.; He, T.C.; Ji, P. Wnt and BMP Signaling Crosstalk in Regulating Dental Stem Cells: Implications in Dental Tissue Engineering. Genes Dis 2016, 3, 263-276. 